\title{
Taurine and Its Derivatives: Analysis of the Inhibitory Effect on Platelet Function and Their Antithrombotic Potential
}

\author{
Adrian Eugen Roşca ${ }^{1,2, *}$, Ana-Maria Vlădăreanu ${ }^{3, *}$, Radu Mirica ${ }^{4} \mathbb{D}$, Cristina-Mihaela Anghel-Timaru ${ }^{1}$, \\ Alina Mititelu ${ }^{3}$, Bogdan Ovidiu Popescu ${ }^{5}$, Constantin Căruntu ${ }^{1,6}{ }^{(D}$, Suzana Elena Voiculescu ${ }^{1}$, Şerban Gologan ${ }^{7}$, \\ Minodora Onisâi ${ }^{3}$ (D), Iuliana Iordan ${ }^{3,8}$ and Leon Zăgrean ${ }^{1}$
}

Citation: Roşca, A.E.; Vlădăreanu, A.-M.; Mirica, R.; Anghel-Timaru,

C.-M.; Mititelu, A.; Popescu, B.O.; Căruntu, C.; Voiculescu, S.E.; Gologan, S..; Onisâi, M.; et al. Taurine and Its Derivatives: Analysis of the Inhibitory Effect on Platelet Function and Their Antithrombotic Potential. J. Clin. Med. 2022, 11, 666. https:// doi.org/10.3390/jcm11030666

Academic Editor: Christine Espinola-Klein

Received: 31 December 2021

Accepted: 26 January 2022

Published: 27 January 2022

Publisher's Note: MDPI stays neutral with regard to jurisdictional claims in published maps and institutional affiliations.

Copyright: (C) 2022 by the authors. Licensee MDPI, Basel, Switzerland. This article is an open access article distributed under the terms and conditions of the Creative Commons Attribution (CC BY) license (https:// creativecommons.org/licenses/by/ $4.0 /)$.
1 Department of Physiology, "Carol Davila" University of Medicine and Pharmacy, 050474 Bucharest, Romania cristina.timaru@umfcd.ro (C.-M.A.-T.); costin.caruntu@gmail.com (C.C.); suzana.voiculescu@umfcd.ro (S.E.V.); leon.zagrean@umfcd.ro (L.Z.)

2 Department of Cardiology, Emergency University Hospital of Bucharest, 050098 Bucharest, Romania

3 Department of Hematology, "Carol Davila" University of Medicine and Pharmacy, Emergency University Hospital of Bucharest, 050098 Bucharest, Romania; alina.mititelu@drd.umfcd.ro (A.M.); minodorel@yahoo.com (M.O.); iuliana.iordan@drd.umfcd.ro (I.I.)

4 Department of Surgery, "Carol Davila" University of Medicine and Pharmacy, "Sf. Ioan" Clinical Hospital, 042122 Bucharest, Romania; mirica_rm@yahoo.com

5 Department of Neurology, "Carol Davila” University of Medicine and Pharmacy, Colentina Clinical Hospital, 020125 Bucharest, Romania; bogdan_ovidiu_popescu@yahoo.com

6 Department of Dermatology, "Prof. N.C. Paulescu" National Institute of Diabetes, Nutrition and Metabolic Diseases, 011233 Bucharest, Romania

7 Department of Gastroenterology, "Carol Davila" University of Medicine and Pharmacy, Elias Clinical Hospital, 011461 Bucharest, Romania; serbangologan@gmail.com

8 Department of Medical Semiology and Nephrology, "Carol Davila” University of Medicine and Pharmacy, 050474 Bucharest, Romania

* Correspondence: adrian.rosca@umfcd.ro (A.E.R.); anamaria.vladareanu@umfcd.ro (A.-M.V.)

\begin{abstract}
Taurine is a semi-essential, the most abundant free amino acid in the human body, with a six times higher concentration in platelets than any other amino acid. It is highly beneficial for the organism, has many therapeutic actions, and is currently approved for heart failure treatment in Japan. Taurine has been repeatedly reported to elicit an inhibitory action on platelet activation and aggregation, sustained by in vivo, ex vivo, and in vitro animal and human studies. Taurine showed effectiveness in several pathologies involving thrombotic diathesis, such as diabetes, traumatic brain injury, acute ischemic stroke, and others. As human prospective studies on thrombosis outcome are very difficult to carry out, there is an obvious need to validate existing findings, and bring new compelling data about the mechanisms underlying taurine and derivatives antiplatelet action and their antithrombotic potential. Chloramine derivatives of taurine proved a higher stability and pronounced selectivity for platelet receptors, raising the assumption that they could represent future potential antithrombotic agents. Considering that taurine and its analogues display permissible side effects, along with the need of finding new, alternative antithrombotic drugs with minimal side effects and long-term action, the potential clinical relevance of this fascinating nutrient and its derivatives requires further consideration.
\end{abstract}

Keywords: taurine; taurine derivatives/analogues; hemostasis/haemostasis; platelet activity; platelet reactivity; platelet aggregation; coagulation; thrombosis; prothrombotic state; thrombotic diathesis

\section{Introduction}

Taurine (2-aminoethanesulfonic acid) is a phylogenetically ancient compound with a large distribution in the biosphere, present in high concentration in algae and animals, including insects and arthropods, but generally absent or nearly absent in bacteria and 
plants. In many animals, including mammals, it is the most abundant low-molecularweight organic constituent. A $70 \mathrm{~kg}$ human body contains up to $70 \mathrm{~g}$ of taurine [1,2]. Although an amino acid, it is not used in protein synthesis [3].

High concentrations in humans are found in bile, myocardium, skeletal muscles, liver, nervous system, intestine, kidney, retina, and blood cells (leukocytes, platelets) $[4,5]$. The endogenous synthesis from methionine and cysteine is insufficient, therefore diet remains the major source of taurine, especially seafood, eggs, and meat. Taurine has a proven benefit as a pharmaconutrient or a conditionally essential amino acid, being administered to subjects requiring long term parenteral nutrition, including newborns or premature infants. It has also gained more and more popularity as an ingredient in food supplements and energy drinks [6-8].

An important step in understanding the action of taurine was reached in 1968, along with the publication of Jacobsen and Smith's comprehensive review [1]. Until that point all known data about its action were reduced to bile salt synthesis, osmoregulation in marine invertebrates, energy storage in marine worms, and neural inhibition in the central nervous system. Since then, the range of its physiological functions has considerably expanded. Nowadays, there is overwhelming evidence about the involvement of taurine in fundamental physiological processes, such as neuromodulation, bile acid conjugation, intestinal microbiota homeostasis, regulation of energy metabolism, muscle contraction, ion transport, calcium handling, immunomodulation, anti-inflammatory and anti-oxidative response, osmoregulation, and cell membrane stabilization and apoptosis [3,4,9-11]. Taurine has been further proved to exert many pharmacologic actions, acting as a protective agent against pathologies including nervous diseases (retinal degeneration, stroke, neurodegenerative diseases-Parkinson's, Alzheimer's, or Huntington's disease-epilepsy, fragile X syndrome, succinic semialdehyde dehydrogenase deficiency), metabolic diseases (diabetes mellitus, stroke-like episodes - MELAS, mitochondrial disease), inflammatory diseases, sarcopenia, myotonic dystrophy, and Duchenne muscular dystrophy [9-11]. Moreover, taurine elicits protection against cardiovascular disease [5,9,12-14], delaying the progression of atherosclerosis [15,16], reducing blood pressure [17-20], preventing the development and correcting cardiomyopathy [21-26], showing efficacy in ischemia-reperfusion injury [9,27], manifesting antiarrhythmic properties, preventing sudden death [28-32], and acting as a cardioprotective agent in congestive heart failure (CHF) [11,33]. As a matter of fact, taurine has been approved to be included in the treatment of CHF in Japan [9]. Generally, no side effects of taurine administration have been reported at regular doses, nor major ones at high doses (over $6 \mathrm{~g} /$ day) [8,11,33-36]. Through all these above mentioned actions, taurine can represent an important future component of the newer promising therapies against cardiovascular disease.

Last but not least, taurine has been proven to manifest inhibitory effects on key processes of hemostasis, such as platelet activation and aggregation. Our descriptive article aims to review available data regarding the influence of taurine and its derivatives on platelet function, focusing on its claimed antithrombotic potential.

\section{Overview of the Antithrombotic Potential of Taurine}

Initial data suggesting a likely antithrombotic role of taurine came from observational studies which identified high levels of taurine in hibernating animals while acclimating to hypothermic conditions. Therefore, taurine has drawn attention through its possible role in freeze tolerance. The hibernating animals are at risk for intravascular thrombosis due to very slow blood flow and increased blood viscosity induced by low temperatures exposure. It has been shown that the total amino acid pool increased more than two-fold in hibernating animals (hatchling turtles, frogs) with taurine accounting for about $50 \%$ of this increase $[37,38]$. Moreover, a decrease in total amino acid plasma levels has been shown in the process of snakes' cold acclimation, except for taurine (the single one that increased). Clotting times prolongation has been recorded when blood humoral coagulation of these 
animals was assessed [38-40]. All these led to an interesting emerging hypothesis regarding the possible role of taurine in preventing blood clotting [37,38].

Next, in vivo experiments have been developed in order to explore the putative antithrombotic activity of taurine. Huang and Rao studied the effect of taurine, separately and in combination with neferine, on platelet aggregation and thrombus formation in rats. Both drugs have been found to inhibit platelet aggregation triggered by various agonists when assessed by turbidimetry, and taurine $(100 \mathrm{mg} / \mathrm{kg})$ reduced the wet weight of induced thrombosis by a rate of $47.82 \%$ vs. control rats [41].

In another rat model of arterial thrombosis (ferric trichloride injection in the abdominal aorta), taurine enhanced urokinase (UK)-induced arterial recanalization compared to UK alone, as concomitant administration of drugs reduced the area of the thrombus crosssection [42]. Later, Murina et al. performed an in vivo experiment of arterial thrombosis [43] using a taurine derivative, $\mathrm{N}, \mathrm{N}$-dichlorotaurine (DT), a compound synthesized via the reaction of taurine with hypochlorite (which is produced in vivo by activated neutrophils in myeloperoxidase-catalyzed reactions). Taurine can act as a trap for "active chlorine", attenuating the oxidative damage induced by hypochlorite and providing cell protection. But most of all, the taurine analog DT seemed to manifest remarkable antithrombotic properties. Intravenous injection of DT (3.4-6.8 mg/ $\mathrm{kg}$, with a blood DT concentration of $0.25-0.5 \mathrm{mM}$ ) $10 \mathrm{~min}$ prior to the intravenous injection of the thrombotic agent ADP $(300 \mathrm{mg} / \mathrm{kg})$, resulted in a reduced mortality rate (up to $10 \%$, compared to $96 \%$ in controls), and a locomotor activity of the survivors returning to normal in 1 to $5 \mathrm{~min}$ after the treatment. In terms of mortality rate, this result appeared to be more valuable than that obtained using ASA $(20 \mathrm{mg} / \mathrm{kg}$, blood concentration of $1.7 \mathrm{mM})$ or ticlopidine $(10 \mathrm{mg} / \mathrm{kg}$, blood concentration of $0.5 \mathrm{mM}$ ), but unfortunately, it lacked statistical power. In a second series of experiments, DT $(6.8 \mathrm{mg} / \mathrm{kg})$ administered before injecting an epinephrine-collagen mixture $(8.6 \mathrm{mg} / \mathrm{kg}$ epinephrine, concomitantly with $15 \mathrm{mg} / \mathrm{kg}$ collagen) was shown to be effective in increasing survival rate from $16 \%$ in controls to $64 \%$ in treated rats. Considering that ASA and ticlopidine doses used in this study were similar to those recommended for a single week of oral treatment, and that used DT doses were lower than those causing acute toxicity (the lethal doses for $50 \%$ of mice were $48 \mathrm{mg} / \mathrm{kg}$, by one order higher magnitude than the therapeutic one), the authors speculated that DT may represent a promising antithrombotic agent [43].

An in vivo rat model of thrombosis using a combination of stasis and hypercoagulability in the inferior vena cava showed lower efficacy in preventing thrombus formation of another taurine derivative, taurolidine ( $10 \mathrm{mg}$, or $20 \mathrm{mg}$, i.v) when compared to lowmolecular weight heparin (nadroparin calcium, 100 antiXa ICU $/ 2 \mathrm{~mL} / \mathrm{kg}$ ). Thrombus weight was significantly lower in the taurolidine-treated group than in controls (a decrease of $42 \%$ ) but remained significantly higher than in the heparin-treated group. It has also been noted that taurolidine elicits only a limited influence on the activity of several plasma coagulation factors (significant reduction of factors V, VIII, IX, XI and XII activities, and insignificant reduction of factors II, VII and X activities), without changing prothrombin time, or activated partial thromboplastin time. The conclusion was that taurolidine is more likely to be ineffective in venous thrombosis prevention in this experimental setting [44].

Based on the concept that atheroembolic lesions dissolution might require both an antithrombotic agent and a lipid emulsifier, a new idea emerged in the 1990s concerning the neuroprotective effects of taurine and its derivatives on ischemic brain damage. Jeynes et al. demonstrated in two successive experiments that combined treatment with taurochenodeoxycholate and streptokinase can reduce the size of in vitro generated thrombi, and dramatically reduce the area and perimeter of the in vivo infarcts in rabbits subjected to cerebral-induced atherothromboembolism $[45,46]$. Moreover, Sun et al. showed that taurine can decrease cerebral infarct volume in rats who underwent transient middle cerebral artery occlusion (MCAo) in a dose-dependent manner $(5,15,50 \mathrm{mg} / \mathrm{kg})$, pointing caspase- 3 and calpain-mediated apoptosis blockage as one of the possible mechanisms for its protective role against focal cerebral ischemia [47]. The authors further reported 
reduced ischemic brain damage with taurine administration $(50 \mathrm{mg} / \mathrm{kg}$, i.v $)$ in a rat model of a stroke, and newly pointed taurine might act via suppression of Poly (ADP-ribose) polymerase (PARP) and nuclear factor-kappaB (NF-kB) pathways [48]. The same research group also demonstrated that taurine and urokinase co-administration after experimental MCAo in rats can widen the therapeutic window, without augmenting the hemorrhagic transformation [49]. They suggested the extension of the therapeutic window following delayed intravenous administration of taurine $(50 \mathrm{mg} / \mathrm{kg})$ may continue up to $8 \mathrm{~h}$ after the experimental induction of stroke [50]. Later, Rukan et al. noted that taurine administration after ischemic-reperfusive brain damage can restore normal endothelial function, inhibit platelet activity and humoral coagulation, and remove brain morphological changes in rats [51]. Gharibani and colleagues concomitantly reported the efficacy of taurine administration in a model of focal rat MCAo, showing a great reduction of the infarcted area, and neuroprotective effects via inhibition of apoptosis and downregulation of the activating transcription factor 6 (ATF6) and inositol requiring enzyme 1 (IRE-1) pathways [52]. Similar effects of taurine on infarct size have been noted following the combined treatment with taurine (40 mg/kg) and S-Methyl-N,N-diethylthiolcarbamate sulfoxide (DETC-MeSO) in transient MCAo, which led to a synergistic suppression of all three pathways of endoplasmic reticulum (ER) stress-induced apoptosis, suggesting an effective novel treatment that might be used in ischemic stroke [53].

Recently, Jin et al. investigated the effect of taurine treatment after thrombolytic therapy with tissue-type plasminogen activator (tPA) in a rat MCAo model. Taurine (50 mg/kg i.v, at $4 \mathrm{~h}$, for 3 days) reduced the infarct size versus saline at $4 \mathrm{~h}$ after the induced stroke, while the combined treatment with taurine (given at the same time-dose) and delayed tPA (10 mg $/ \mathrm{kg}$, at $6 \mathrm{~h}$ ) was more effective than tPA therapy alone $(10 \mathrm{mg} / \mathrm{kg}$, at $2 \mathrm{~h})$. Taurine has also been proved to markedly reduce the intravascular fibrin depositions and thrombocytes accumulation in downstream microvessels (inhibiting secondary thrombus formation associated with early reperfusion). Therefore, taurine may enhance the efficacy of thrombolysis, and may extend the therapeutic window duration of tPA from 2-3 h to $6 \mathrm{~h}$ after embolic MCAo in rats. Additionally, taurine administered in combination with delayed t-PA has been shown to profoundly prevent tPA-associated hemorrhage (6 $\mathrm{h}$ after the onset of ischemia), to reduce mortality rate at 3 days from $47 \%$ to $21 \%$, to significantly improve the long-term outcome after stroke, and to reduce the 45-day mortality rate from $55 \%$ to $31 \%$ (following 7 days taurine administration). Taurine seems to reduce tPA-associated hemorrhage acting through a profound inhibition of CD147 (cluster of differentiation 147)-dependent MMP-9 (matrix metalloproteinase-9) pathway in the ischemic brain endothelium [54]. On the other hand, it is well known that CD147 is involved in intravascular fibrin and platelet deposition, by interacting with platelet GP VI (glycoprotein VI), and its inhibition has been proven to reduce microvascular thrombosis in acute ischemic stroke [55-57]. Thereby, as suggested by Jin et al. [54] and previously by Sun M. et al. [48], intense downregulation of CD147 expression, and inhibition of NF- $\mathrm{B}$ activation by taurine may underlie its beneficial influence in terms of improving the cerebral microvascular patency following tPA thrombolysis in rat embolic MCAo. Jin and colleagues concluded that taurine exerts potent anti-thrombotic effects, and the combination of taurine and tPA may be clinically relevant as a new future strategy in embolic stroke therapy.

Animal models of thrombosis seem to provide consistent evidence regarding the antithrombotic potential of taurine and its derivatives. However, further preclinical experiments need to be carried out, in order to produce a natural transition towards clinical trials. Due to ethical considerations, although highly needed, prospective human studies on thrombosis outcomes are very difficult to achieve. Up-to-date knowledge regarding the overall assessment of taurine effectiveness in human thrombotic conditions is only based on few observational and prospective-case control trials. One of these studies is the one published by Ijiri et al. in 2013, investigating the antithrombotic effect of the sulfuramino acid on 101 enrolled healthy Japanese volunteers reporting a taurine-rich diet. The protocol used a new point-of-care test (a Global Thrombosis Test-GTT) that allowed the 
assessment of the entire hemostatic process (platelet reactivity, humoral coagulation, and endogenous thrombolytic activity). While nonsignificant correlations have been observed between taurine concentration in urine samples and GTT-Occlusion Times measured in nonanticoagulated blood samples of volunteers, a significant inverse correlation has been registered between urinary taurine concentration and GTT-Lysis Times, suggesting that a taurine-rich diet may enhance spontaneous thrombolytic activity [58]. Since 1985, the same research group has conducted several multicenter epidemiological studies based on data from World Health Organization (WHO) surveys on diets and cardiovascular disease (CVD) risk and mortality (the largest covering 61 populations in 25 countries, including men and women). Urinary taurine excretion per $24 \mathrm{~h}$ (24-UT) has been used in these trials as a biomarker for dietary taurine intake. A significant inverse correlation between 24-UT and mortality rate from stroke and coronary heart disease (CHD) has been reported [59-64]. On the other hand, a prospective nested case-control study, including 14,274 women from a breast cancer screening center enrolled since 1985 and until 1991, revealed no statistically significant association between serum taurine and stroke risk. The aforementioned epidemiological study noted however a significant inverse correlation of these parameters in the never-smokers subgroup, information deserving further consideration [65].

Direct human data related to the possible anti-thrombotic role of taurine in patients with thrombosis are scarce, due to methodological limitations. However, there is a considerable larger amount of indirect data coming from human and animal studies assessing taurine and its derivatives' action on a distinct key process of hemostasis - platelet activation, with subsequent aggregation. These studies will be discussed in the next sections.

Besides taurine influence on hemostasis per se, its beneficial action in terms of shifting hemostatic balance to a lower hypercoagulant status may be also linked to its favorable influence on cardiovascular risk markers. Taurine has been proved to delay atherosclerosis onset by diminishing cholesterol biosynthesis rate, decreasing hepatic and serum cholesterol level, reducing hepatic biosynthesis of cholesterol esters and triglycerides, decreasing hyperhomocysteinemia, suppressing lipoxygenase 1 (LOX-1) expression, protecting endothelial cells from the toxicity generated through oxidation and glycation of LDL, downregulating vascular smooth muscle cell (VSMC) proliferation through platelet-derived growth factor-BB (PDGF-BB) inhibition, increasing vascular production of nitric oxide, and generally attenuating the neointimal inflammation and oxidative stress [11,16,66-79]. Apart from the protective effect regarding dyslipidemia, taurine also positively influences other components of metabolic syndrome (obesity, hypertension, and diabetes), and even showed effectiveness in combating diabetes complications, including nephropathy, retinopathy, neuropathy, and cardiomyopathy [17,20,79-85]. Because these cardiovascular risk markers have also been independently associated with coagulation abnormalities, such as enhanced platelet aggregation, activated humoral coagulation, or suppressed fibrinolysis [86-96], there is reason to believe the antithrombotic properties of taurine could partially be ascribed to its beneficial influence on these conventional cardiovascular risk factors. Finally, taurine has the ability to induce structural "reverse-remodeling" following myocardial injury, reducing oxidative stress, apoptosis, myocardial hypertrophy and fibrosis as a reparative process [27,97-102]. Thereby, taurine contributes to the attenuation of the functional (electrical) remodeling and diastolic function impairment, leading to a reduced risk for arrhythmias onset [29-32,103], which would otherwise predispose to intracavitary thrombosis and further systemic embolism.

\section{Overview of Platelet Function}

The involvement of platelets in normal hemostasis and vascular disease is well known. Platelets' functions in hemostasis and thrombosis have been extensively studied in the past decade, providing a valuable insight into the elements and signals regulating platelet adhesion, activation and aggregation [104]. For an efficient hemostasis, it is mandatory that the mechanisms leading to platelet adhesivity, granule release, platelet activation and aggregation happen simultaneously (Figure 1). 


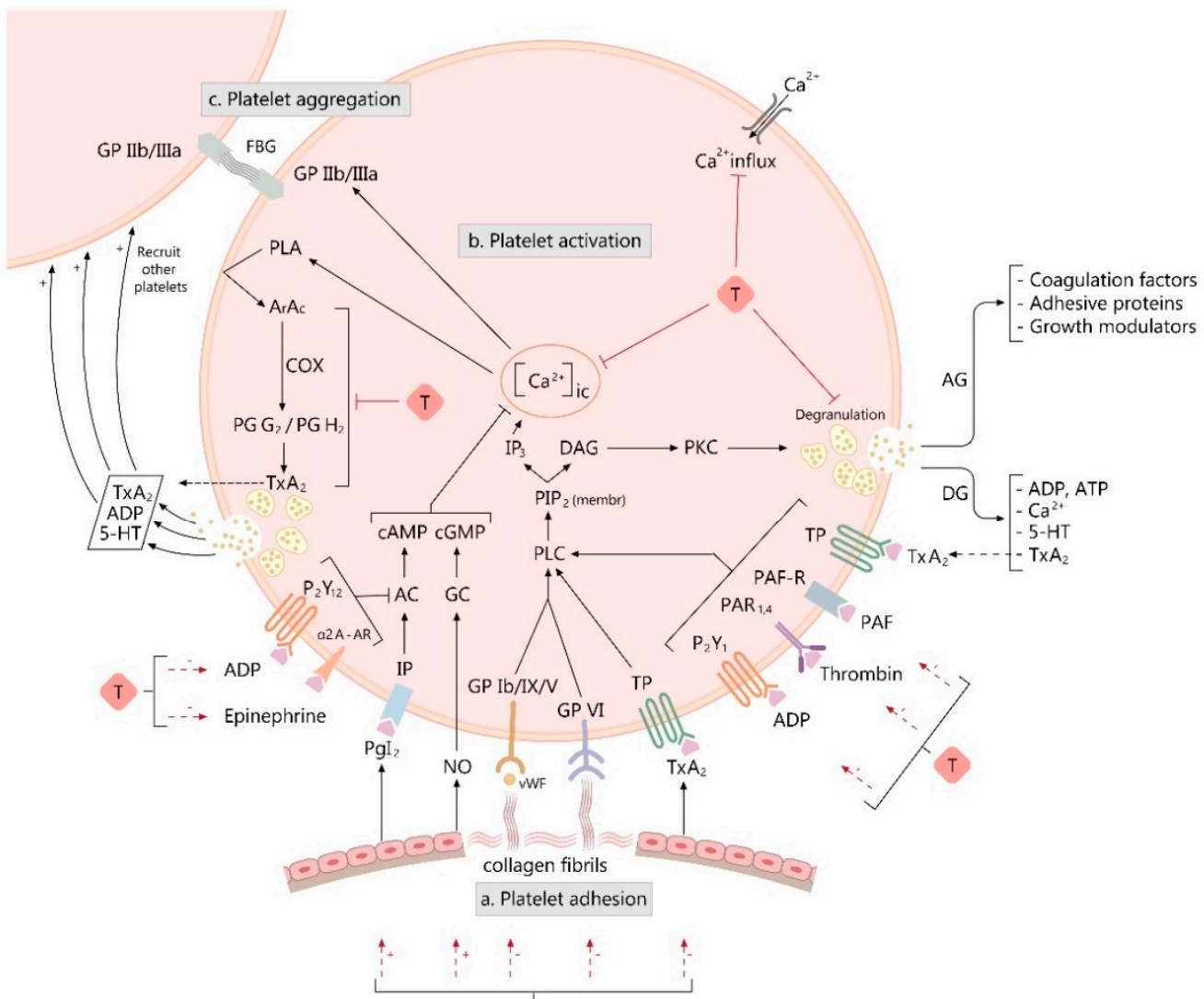

Figure 1. Figure illustrating the influence of taurine and its derivatives $(\mathrm{T})$ on various processes involved in platelet activation and aggregation. The proposed mechanisms of action (indicated by red arrows) are the following: 1 . T inhibits platelet aggregation triggered by collagen, which is a strong platelet activator, but also an adhesion surface, being responsible for platelet adhesion (a); 2. $\mathrm{T}$ inhibits platelet activation and secretion (b) and consequently the process of platelet aggregation (c) by: (1) controlling intracellular calcium concentration- $\left[\mathrm{Ca}^{2+}\right]_{\text {ic }}$ (limiting the calcium influx and suppressing the intraplatelet calcium $\left(\mathrm{Ca}^{2+}\right)$ response to activating agonists); (2) down-regulating a growth modulator, $\beta$-thromboglobulin $(\beta-\mathrm{TG})$ and adenosine triphosphate (ATP) release response to agonists, as markers of discharge from alpha and dense platelet granules; (3) decreasing the platelet cyclooxygenase activity and the platelet thromboxane $\mathrm{A}_{2}\left(\mathrm{TxA}_{2}\right)$ production; (4) suppressing platelet aggregation triggered by various agonists, such as adenosine diphosphate (ADP), thrombin, epinephrine, or platelet activation factor (PAF); (5) increasing of the endothelial nitric oxide (NO) release and prostacyclin $\left(\mathrm{PgI}_{2}\right)$ production and decreasing $\mathrm{TxA}_{2}$ release. Other used abbreviations: GP—glycoprotein; vWF-von Willebrand factor; FBG—fibrinogen; PLC—phospholipase C; $\mathrm{PIP}_{2}$ (membr) - phosphatidylinositol 4,5-bisphosphate from platelet plasmalemma; $\mathrm{IP}_{3}$-inositol 1,4,5-trisphosphate; DAG-1,2-diacylglycerol; PKC—protein kinase C; DG—dense granule; AG—alfagranule; 5-HT-5-hydroxytryptamine; PAF-R-PAF receptor; $\mathrm{PAR}_{1,4}$ - protease-activated receptor-1 and -4; $\mathrm{P}_{2} \mathrm{Y}_{1}$ - purinergic receptor $2 \mathrm{Y}_{1} ; \mathrm{P}_{2} \mathrm{Y}_{12}$ - purinergic receptor $2 \mathrm{Y}_{12}$; IP-prostacyclin receptor; $\mathrm{TP}-\mathrm{Tx} \mathrm{A}_{2}$ receptor; $\alpha 2 \mathrm{~A}-\mathrm{AR}$-alpha $2 \mathrm{~A}$ adrenergic receptor; $\mathrm{AC}$-adenylyl cyclase; $\mathrm{cAMP}$ cyclic adenosine monophosphate; GC—guanylate cyclase; $\mathrm{CGMP}$ — cyclic guanosine monophosphate; PLA—phospholipase A; ArAc—arachidonic acid; COX—cyclooxygenase; $\mathrm{PgG}_{2}$ — prostaglandin $\mathrm{G}_{2}$; $\mathrm{PgH}_{2}$ - prostaglandin $\mathrm{H}_{2} ;(+)$ on the arrow represents up-regulation, (-) on the arrow represents down-regulation.

Following blood vessel injury, platelets interact with collagen fibrils in the exposed subendothelium by a process (adhesion) that involves, among other events, the interaction of von Willebrand factor (vWF) plasma protein with a specific glycoprotein (GP) complex 
on the platelet surface, GP Ib/IX/V. This promotes direct interaction of collagen receptors (GPVI and $\alpha 2 \beta 1$ integrin) on platelets with collagen fibrils from the subendothelial matrix, initiating the process of platelet activation. Collagen is an important participant, as it represents both an adhesion surface and a strong platelet activator [105].

Platelet activation and granule release are influenced by humoral mediators (platelet activating factor-PAF, thrombin, epinephrine), substances released from activated platelets (platelet agonists like adenosine diphosphate-ADP, serotonin, thromboxane $\mathrm{A}_{2}-\mathrm{TxA}_{2}$ ), and vessel wall extracellular matrix constituents that come in contact with adherent platelets (collagen). Signal transduction is initiated at the binding receptors of platelet activators: GPVI for collagen, GPIba for vWF; protease-activated receptor-1 and -4 (PAR 1 and PAR 4) for thrombin, purinergic receptors $2 Y_{1}$ and $2 Y_{12}\left(P_{2} Y_{1}, P_{2} Y_{12}\right)$ for ADP, thromboxane receptor (TP) for $\mathrm{TxA}_{2}$; alpha $2 \mathrm{~A}$ adrenergic receptor (alfa2A-AR) for epinephrine, and platelet activation factor receptor (PAF-R) for platelet activation factor (PAF) [106].

Agonists binding to platelet receptors initiates the activation process, starting with activation of phospholipase C (PLC) isoforms which hydrolyse phosphatidylinositol 4,5-bisphosphate $\left(\mathrm{PIP}_{2}\right)$ producing second messengers-1,2-diacylglycerol (DAG) and 1,4,5-trisphosphate $\left(\mathrm{IP}_{3}\right)$ - which trigger intracytosolic calcium elevation. $\mathrm{IP}_{3}$ binds to its receptor on dense reticular system (DTS) membrane and opens $\mathrm{Ca}^{2+}$ channels, producing an increase in cytosolic $\mathrm{Ca}^{2+}$ concentration [107]. High intracellular calcium is associated with platelet shape shifting, procoagulant surface exposure, secretion of platelet granular content, further activation of surface glycoproteins, activation of phospholipase A (PLA) and protein phosphorylation, all necessary for $\alpha_{\mathrm{IIb}} \beta_{3}$ integrin (aka GP Ilb/IIIa) activation. DAG activates protein kinase C (PKC), a key player in platelet secretion and activation of GP IIb/IIIa. PLA releases arachidonate from membrane phospholipids, then $\mathrm{TxA}_{2}$ is synthetized, inducing further platelet recruitment and promoting thrombus formation [105].

Transient platelet activation is inhibited by both endothelial prostaglandin $\mathrm{I}_{2}$ or prostacyclin $\left(\mathrm{PgI}_{2}\right)$ and nitric oxide (NO). $\mathrm{PgI}_{2}$ acts on its receptor (IP) and activates adenylyl cyclase (AC), increasing cyclic adenosine monophosphate (cAMP). NO acts on guanylate cyclase (GC), rising cyclic guanosine monophosphate (cGMP) levels. High cAMP and cGMP platelet levels are associated with the attenuation of cytosolic $\mathrm{Ca}^{2+}$ increase in response to agonists, an accelerated DTS uptake of intracellular $\mathrm{Ca}^{2+}$, impaired platelet secretion, and inhibition of $\alpha_{\mathrm{IIb}} \beta_{3}$ integrin activation. AC activity is inhibited by ADP via P2Y 12 receptor and by epinephrine via alfa2A-AR, in order to facilitate platelet activation [105].

Upon activation, platelets granule content is released, further promoting adhesion and activation of other platelets. Activated platelets form a clump at the site of the vessel injury in a process called aggregation. Aggregation involves the formation of fibrinogen bridges in between platelets, following the activation of GPIIb-IIIa, a fibrinogen and vWf platelet transmembranary receptor [105].

\section{Taurine and Platelet Function}

Because taurine was seen as a non-patentable nutrient, the pharmaceutical industry has not shown much interest in its research. Most nutritionists have not paid much attention to it maybe because taurine represents a "semi-essential" or "conditional" amino acid, and not an essential one. Fortunately for the scientific world, as McCarty very well remarked, "physiologists have taken up the slack" in defining its role, followed by reports of a promising pharmacological action, especially in the recent years [108].

Platelets play a key role in the physiology and pathophysiology of hemostasis. The beneficial influence of taurine on the complex process of hemostasis may be primarily ascribed to its action on platelets. In this regard, one of the simplest tests that can be performed is assessing platelets taurine content, which depends on whole body taurine.

\subsection{Taurine Content of the Platelets}

Platelets are known to contain all essential amino acids. Taurine is present in platelets in a six times higher concentration than any other amino acid. From Maupin's data, taurine 
platelet-plasma gradient is 440:1 [109]. Ahtee et al. suggested that taurine intra-platelet accumulation occurs against platelet-plasma concentration gradient. Platelet in vitro ability to accumulate radiolabeled taurine from the surrounding environment is based on the existence of an active transporter, which is responsible for generating and maintaining a high platelet-plasma concentration gradient [110]. A direct correlation, influenced by taurine intake, between platelet and plasma taurine concentrations has been reported in cats and humans [111-113]. A human study conducted in diabetic patients found a lower level of both plasma and platelet taurine in diabetic subjects compared to healthy controls, associated with a reduced uptake and an elevated taurine release from platelets. This has raised the question of whether there could be changes in the function of the two-carrier systems (with low and high affinity) that might lead to that reduction in platelet taurine content $[114,115]$. More recently, an animal study compared platelet taurine level in taurinedeficient dogs and taurine-sufficient dogs. A direct correlation between platelet and plasma taurine concentration has been established when data have been analyzed for each group. In the taurine-sufficient group, platelet taurine level was better correlated with its blood level than in the taurine-deficient group [116].

Platelet taurine concentration in animals or humans can be predicted by knowing plasma or whole-body taurine concentration. However, plasma taurine is not as a good predictor as platelet taurine level for platelet function, because platelets are able to accumulate taurine against a plasma-platelet concentration gradient $[113,117,118]$. The level of platelet taurine accumulation could be an important contributor to the inhibitory effects of the sulfur-amino acid on platelet function, as described further below.

\subsection{Taurine Influence on Platelet Hemostatic Activity}

Taurine and related compounds have been repeatedly pointed as modulating factors of platelet function $[113,119]$, but the interest regarding their influence on blood coagulation dates from the early 1950s and 1960s [120,121]. Research on taurine effects over hemostasis started with the observation that bile acids (such as taurocholic, taurodeoxycholic, or taurochenodeoxycholic acid) and their salts elicit a considerable inhibition on platelet aggregation induced by various agonists (ADP, collagen, and others) [122-125]. It has been assumed that a probable impaired platelet aggregation in the upper segment of the gastrointestinal tract induced by biliary reflux might partly explain the poor hemostatic response in these otherwise normal human subjects [122].

These observations opened a new perspective on taurine and derivatives' influence on the complex process of hemostasis, which was further greatly exploited.

For easier reading, a division based on animal and human studies has been established.

\subsubsection{Evidence from Animal Studies}

Platelet function impairment plays a pivotal role in the onset and development of arterial thrombosis. Thus, finding new antithrombotic drugs, with or without minimal adverse effects is a subject of great interest. To date, animal studies provide substantiating evidence regarding the inhibitory action of taurine (and its related compounds) on platelet function, some of these studies even suggesting a putative antithrombotic potential of the sulfur-containing amino acid. The representative articles have been summarized and tabulated in Table 1.

One of the early experimental in vitro studies exploring the effect of taurine on platelet activity and reactivity was conducted by Kurachi et al. (1987) in guinea pigs. He demonstrated that taurine preincubation $(40 \mathrm{nM})$ with platelet-rich plasma (PRP) from these animals can inhibit PAF-induced platelet aggregation. This sustained another important finding in the second ex vivo part of this study, showing a reduction in PAF or serotonininduced bronchoconstriction following taurine administration $(50 \mathrm{mg} / \mathrm{kg}$, iv). Since PAF is involved in platelet degranulation with serotonin release, and since the bronchoconstrictor response to PAF has been noted to diminish the effect of a following prostacyclin or antiplatelet antibody pretreatment, it has been suggested that the observed suppressive action 
of the sulfur-amino acid on PAF-induced bronchospasm might be caused by an inhibitory effect on platelet aggregation [126].

El Tahir et al. (1987) demonstrated concomitantly that taurine may be involved in the regulation of prostaglandins (PGs) synthesis in various organs of female rats. Taurine administration (100 or $200 \mathrm{mg} / \mathrm{kg} /$ day) in drinking water for 6 weeks resulted in an elevation of aortic and uterine $\mathrm{PgI}_{2}$ and a diminution of uterine $\mathrm{TxA}_{2}$ release. Moreover, taurine incubation $(0.4$ and $0.8 \mathrm{mM})$ with tissues from 18-day pregnant rats enhanced uterine and aortic $\mathrm{PgI}_{2}$ release. These results globally suggested a potential benefit of taurine in those diseases presenting with a deficiency in $\mathrm{PgI}_{2}$ release [127].

A few years later, Hayes et al. (1989) showed in an ex vivo trial that taurine supplementation in cats' diet ( $0.5 \mathrm{~g}$ taurine per kilogram) led to a significantly higher $(140 \%)$ platelet aggregation threshold $\left(\mathrm{PA}_{\mathrm{t}}\right.$, defined as the amount in $\mu \mathrm{g}$ of collagen required to elicit $10 \%$ of the predetermined maximum aggregation in $1 \mathrm{~mL}$ PRP) than in taurine-depleted cats [113]. They also found that $\mathrm{PA}_{t}$ increase was associated with a higher concentration of platelet and plasma taurine, as well as platelet glutathione, the latter being known to diminish sensitivity to aggregating stimuli [128]. Arterial thromboembolism in cats with taurine-deficiency syndrome has been attributed to cardiomyopathy development, and it is apparently caused by mural thrombi formation and embolization from the left failing heart $[21,129]$. In their study, Hayes and colleagues speculated that taurine depletion in cats could actually induce both cardiomyopathy and thromboembolic phenomena [113]. On the other hand, Welles et al. (1993) reported reduced platelet aggregation and platelet serotonin release triggered by ADP, as well as an unchanged aggregation and mild increase of platelet serotonin release following collagen stimulation, in taurine-deficient versus taurine-repleted cats. The author noted that increased sensitivity to collagen and decreased responsiveness to ADP observed in taurine-deficient cats was quite surprising, considering that irreversible platelet aggregation following an initial sufficient stimulus is reached with dense granules ADP release [130].

At that time, another study showed that taurine $(30 \mathrm{mg} / \mathrm{kg} /$ day, for 9 weeks) is effective in decreasing the elevated magnitude of ADP or thrombin-induced platelet aggregation in two-kidney-one-clip (2k-1c) Goldblatt renovascular hypertensive rats. However, taurine could not restore the increased level of aggregation in $2 \mathrm{k}-1 \mathrm{c}$ rats to that noted in normal rats; but co-treatment with enalapril ( $6 \mathrm{mg} / \mathrm{kg} /$ day, for 9 weeks) had a complementary effect, restoring aggregation magnitude in $2 \mathrm{k}-1 \mathrm{c}$ rats to that found in normal rats. Considering the quite similar results obtained by the authors on blood pressure and LVW/BW (left ventricular weight/body weight) ratio, it has been concluded that the two drugs, i.e., taurine and enalapril, may potentate each other and may be considered useful in hypertension treatment [131]. The same research group also demonstrated that taurine $(100 \mathrm{mg} / \mathrm{kg}) \mathrm{can}$ inhibit in vivo thrombosis generation and suppress ADP, collagen or thrombin-triggered aggregation (a reduction of platelet aggregation by a rate of $37.40 \%, 44.41 \%$, and $37.87 \%$, respectively, vs. controls) in rats. Moreover, concomitant treatment with taurine and neferine has been shown to be effective in reducing $\mathrm{TxA}_{2}$ generation in rat PRP, without affecting plasma $\mathrm{PgI}_{2}$ production, therefore suggesting a possible mechanism to underlie the effect of the two drugs administration on platelet aggregation and induced-thrombus formation [41].

The antiaggregant effect of taurine has also been noted in a rat model of hypercholesterolemia. Daily supplementation with 5\% taurine in Sprague Dawley rats fed with a cholesterol diet for 4 weeks resulted in a suppression of whole blood platelet aggregometry, a method that has the advantage of being conducted under nearly physiological conditions. The maximum ADP $(2 \mu \mathrm{M})$-induced platelet aggregation at the point where aggregation dissociates was significantly decreased both in taurine vs. control group $(14.36 \pm 1.85$ vs. $19.46 \pm 3.20$ ), and in the mixed-fed (cholesterol and taurine) vs. cholesterol-alone-fed group (14.20 \pm 3.06 vs. $17.13 \pm 3.72)$. The inhibition of platelet aggregation, along with the hypolipidemic and hypocholesterolemic effects of taurine revealed by this study indicate 
a possible favorable action of the sulfur-amino acid in the prevention of cardiovascular disease [132].

Using Born aggregometric method, we demonstrated that taurine (2\% supplemented in drinking water) can decrease platelet aggregation in either normal rats, or in those concomitantly receiving a supraphysiological AAS (anabolic androgenic steroids) dose (10 mg/kg, weekly intragluteal injection, for 3 months) [133]. In a following thromboelastographic (TEG) experiment assessing shear elasticity of the clotting blood, we detected a slight tendency (without reaching statistical significance) of taurine to decrease maximal clot strength and stability in either normal or mixed treated group of rats [134].

Interestingly, there are data showing that the antiaggregant action of taurine can be translated to its derivatives. In 2002, Murina et al. resumed previous studies performed by her colleagues in humans and revealed novel antithrombotic properties of the chloramine derivative DT. In the first in vivo part of the experiment, she used an animal model of thrombosis (results already presented in the previous section and Table 1). The following ex vivo part of this study showed that intravenous injection of DT $(6.8 \mathrm{mg} / \mathrm{kg})$ led to a $50 \%$ decrease of ADP $(10 \mu \mathrm{M})$-triggered platelet aggregation in platelet-enriched plasma from the test group, compared to controls. The author concluded that the antithrombotic effects of chloramine derivatives of taurine may be attributed to their ability to down-regulate platelet activity [43]. To sustain the antiplatelet effect of DT, Murina et al. demonstrated, in an in vitro study using a kinetic nephelometric technique, that DT can also suppress the initial ADP-induced platelet aggregation (formation of small aggregates) in rabbit platelets, and that its effect may be ascribed to platelet sulfhydryl groups changes [135]. DT in a concentration of $10 \mu \mathrm{M}$ reduced by half the intensity of small-angle light scattering aggregation triggered by $0.2 \mu \mathrm{M}$ ADP in isolated rabbit platelets, while DT addition in a moderate concentration (10 millimoles/L) to rabbit blood was shown to markedly inhibit the impedance measured by whole blood aggregometry, triggered by $10 \mu \mathrm{M}$ ADP [136]. A rank of efficacy in suppressing initial aggregation of isolated rabbit platelets was established for several taurine chloramine derivatives. DT, was found to be the most effective, providing a 50\% decrease of PA at a concentration of about $0.2 \mathrm{mM}$, whereas N-chlorotaurine (CT) and Nchloro-N-methyltaurine (CMT) showed an inhibition of only $10 \%$ of PA induced by $10 \mu \mathrm{M}$ $\mathrm{ADP}$ at a concentration of $0.5 \mathrm{mM}$. This behavior was explained through an enhanced reactivity of DT (compared with CT or CMT) for sulfhydryl groups on platelet surface. DT exhibited the greatest velocity constant $\left(>10^{3} \mathrm{M}^{-1} \times \mathrm{s}^{-1}\right)$ when reacting with reduced glutathione comparing with NC $\left(5.90 \pm 1.12 \mathrm{M}^{-1} \times \mathrm{s}^{-1}\right)$ or CMT $\left(3.20 \pm 1.04 \mathrm{M}^{-1} \times \mathrm{s}^{-1}\right)$. Another important finding in this study was that the antiaggregant effects of taurine chloramines are potentiated by the presence of serum albumin (aggregation magnitude of taurine derivatives was 2-fold higher in the presence of albumin). Since albumin also exposes sulfur-containing groups, formation of protein-chloramine complexes could generate changes in protein conformation, providing a more effective interaction with platelets [137]. New derivatives of taurine chloramines have been later developed using a computational quantum-mechanic estimation (a computer calculative prediction) in order to enhance the charges of active chlorine, and therefore to increase the stability and reactivity of taurine derivatives for the thiol groups (such as those exposed by reduced glutathione, amino acids, peptides, or ADP receptors). N-acetyl-N-chlorotaurine and N-propionyl-Nchlorotaurine are examples of amido-derivatives of taurine chloramines with the greatest charge of active chlorine. They exhibited an elevated reactive ability (chemoselectivity) with respect to various sulfur-containing groups in amino acids and peptides and proved a firm inhibition of platelet aggregation triggered by ADP or collagen. Their effect on aggregation might be ascribed to the chemoselectivity and modification of the thiol group in P2Y ${ }_{12}$ ADP receptor, similar to that elicited by the main covalent inhibitors of platelets, the thienopyridine compounds (clopidogrel, prasugrel) [138]. Furthermore, an in vitro comparison between the antiaggregant effect of the amide analog of taurine chloramine, $\mathrm{N}$-propionyl-N-chlorotaurine (PCT) and the alkyl analog, N-isopropyl-N-chlorotaurine (IPCT) was performed. PCT addition in a concentration of $1 \mathrm{mM}$ on rabbit PRP suppressed 
platelet aggregation to a greater extent $(38 \pm 4.1 \%)$ than $1 \mathrm{mM}$ of IPCT $(60 \pm 4.2 \%)$, following stimulation with $10 \mu \mathrm{M}$ ADP. On the other hand, inhibition of platelet aggregation was similar when triggered with $32 \mu \mathrm{g} / \mathrm{mL}$ of collagen. The positive charge of active chlorine and the charge modulus of the nitrogen atom were 5- and 1.4-fold higher, respectively, in the amide than in the alkyl analog. The stronger platelet aggregation suppression of amide derivatives compared to alkyl analogs of taurine chloramines may in fact depend on the more efficient modification of the sulfhydryl group of ADP receptor [139].

\subsubsection{Evidence from Human Studies}

There is a growing body of evidence depicting the influence of taurine on human platelet function, confirming the encouraging outcomes from animal studies.

Almazov et al. (1985) was one of the first to describe the effect of taurine on platelet aggregation, and to underline a possible mechanism of its action. Taurine incubation $(25 \mathrm{nM})$ with human PRP resulted in a decrease of both spontaneous and induced (by $3.5 \mu \mathrm{M}$ ADP) platelet aggregation rate, in the taurine treated platelets vs. control platelets $(1.0 \pm 0.3$ vs. $2.1 \pm 0.6$, and $30.3 \pm 5.8$ vs. $62.8 \pm 9.8$, respectively). In the same in vitro study, taurine $(25 \mathrm{mM}$ ) was also shown to enhance platelet $\mathrm{Ca}, \mathrm{Mg}$-ATPase activity by $45 \%$, an effect proven to be mediated through the stimulatory action of taurine on calmodulin [140] (Table 2).

These findings are consistent with those reported by Raghu et al. (1982), who previously detected an in vitro dose-dependent inhibition of aggregation by taurine addition to platelets, when triggered by ADP, epinephrine, and collagen. This process seemed to involve a mechanism related to $\mathrm{Ca}^{2+}$ (calcium) ion translocation and was enhanced by increasing alkalinity [141].

Later, taurine influence on platelet aggregation has been assessed ex vivo. Hayes et al. (1989) demonstrated that taurine supplementation for 8 days in the diet of nonsmokers, normolipidemic, healthy male volunteers led to an increased plasma and platelet taurine concentration, as well as to a higher $\mathrm{PA}_{\mathrm{t}}$ (an increase by $25 \%$, or $72 \%$ following taurine administration in a dose of $400 \mathrm{mg} /$ day, or $1600 \mathrm{mg} /$ day, respectively) [113]. The percent increase of $\mathrm{PA}_{\mathrm{t}}$ in this study was positively and relatively good correlated $(\mathrm{r}=0.71$, $p<0.005$ ) with the percent increase of platelet taurine concentration, at both taurine doses. Furthermore, a decreased platelet $\mathrm{TxB}_{2}$ (thromboxane $\mathrm{B}_{2}$ ) release has been noted following stimulation of PRP from individuals supplemented with $1600 \mathrm{mg} /$ day (for 8 days) with a constant amount of collagen $(0.93 \mu \mathrm{g})$. Moreover, platelet GSH (glutathione) concentration analysis revealed an elevation of $34 \%$ in the taurine treated group ( $400 \mathrm{mg} /$ day, for 8 days) versus controls, an important finding considering previously reported GSH inhibition on platelet aggregation [128,142]. All these results made the authors conclude that platelet taurine level depends on taurine intake, reflects the global taurine status of the organism, and certainly influences the magnitude of collagen-induced platelet aggregation. Taurine's antiaggregant action may be partly ascribed to its sparing effect on platelet GSH pool [113].

Without showing an obvious effect per se, taurine has been found to markedly potentiate the in vitro inhibitory action of aspirin on collagen-induced platelet aggregation in PRP from healthy volunteers, in a dose-dependent manner [143]. This raised the question whether taurine might be useful in the future as a complementary therapy in patients treated with low-dose aspirin, aiming to decrease the thromboembolic risk [144]. Several years later, resuming their studies on the antiaggregant effect of taurine, Franconi et al. investigated its influence on platelets sampled from insulin-dependent diabetes mellitus (IDD) or non-insulin-dependent diabetes mellitus (NIDD) subjects $[145,146]$. They first noted a reduced level of both plasma and platelet taurine in IDD patients versus healthy subjects, and only a decrease of platelet taurine in NIDD patients. Preincubation of taurine (10 mM) with PRP from IDD patients shifted the whole dose-response curve of platelet aggregation to the right, depending on variable doses of arachidonic acid (from 0.2 to $1 \mathrm{mM}$ ), whereas the diagram remained unchanged in NIDD and in healthy patients. Additionally, an inverse dose-dependent relationship between taurine concentration and the magnitude 
of platelet aggregation has been revealed at a fixed agonist dose $(0.6 \mathrm{mmol} / \mathrm{L}$ of arachidonic acid) in IDD patients. Following in vitro studies, in a second series of experiments conducted in IDD patients subjected to a taurine supplemented diet (intake of $1.5 \mathrm{~g} / \mathrm{day}$, for 3 months), an increase of both plasma and platelet taurine compared to base-line values was registered, as well as a reduced arachidonic acid-induced platelet aggregation. $\mathrm{ED}_{50}$ of arachidonic acid (representing the effective dose of the agonist necessary to reach a $50 \%$ magnitude of maximal aggregation) was significantly decreased $(0.44 \pm 0.07 \mathrm{mmol} / \mathrm{L})$ in IDD patients compared to controls $(0.77 \pm 0.02 \mathrm{mmol} / \mathrm{L})$ at the beginning of the experiment, while chronic taurine intake practically restored $\mathrm{ED}_{50}$ level $(0.72 \pm 0.04 \mathrm{mmol} / \mathrm{L})$ to that of controls. Moreover, taurine supplementation shifted to the right the dose-response curve of platelet aggregation magnitude to increasing concentrations of arachidonic acid (up to $1 \mathrm{mmol} / \mathrm{L}$ ) in IDD patients $[145,146]$. According to these data, the authors suggested that taurine's potential to suppress platelet aggregation in diabetic patients may reduce complications, such as micro- and macroangiopathies, taurine being reported to exert a beneficial influence in retinopathy, renal damage, and cardiomyopathy [21,146-148].

On the other hand, no effect on platelet aggregation has been evidenced in a randomized, double blinded, crossover trial conducted in men with predisposition to type II diabetes mellitus. Taurine in a dose of $1.5 \mathrm{~g}$ daily supplemented in diet for two 8-week periods (and separated by 2 weeks of washout) exerted no influence on ADP-induced platelet aggregation. The lack of effect on aggregation was explained by an insufficient taurine plasma level reached following drug intervention [118].

Taurine influence on platelet function has been assessed in other clinical conditions, such as gestosis. When accompanied by edema, proteinuria, and hypertension (EPH gestosis), it has been linked to a hypercoagulative state $[149,150]$, raising the risk of thrombosis [151,152]. Evidence suggests that platelet activation (measured by markers such as mean platelet volume, P-selectin, CD 63) is higher among woman with EPH gestosis. [152]. However, there are conflicting data regarding platelet aggregation in these patients, some studies reporting an increase, whereas other indicating a decrease of aggregation [153]. In their attempt to explain the coagulation abnormalities in EPH gestosis, Otani et al. (1992) evidenced an increased content of taurine in platelets and a higher in vitro taurine uptake into platelets, when the group of severe EPH gestosis patients was compared to normal pregnancy group, as well as with mild and moderate EPH gestosis group. The increase of taurine uptake by platelets was highly and positively correlated to the severity of EPH gestosis. Plasma taurine concentration was found unchanged in all groups of women [117]. In a following study, the same research group demonstrated that aggregation and platelet release response-measured as $\beta$-thromboglobulin ( $\beta$-TG) and adenosine-triphosphate (ATP) discharge-were significantly reduced in EPH gestosis patients than in normal pregnant or non-pregnant women, when washed platelet suspension (WPS) obtained from these subjects was triggered with ADP $(1 \mu \mathrm{M})$ or collagen $(1 \mu \mathrm{g} / \mathrm{mL})$. They also found that taurine inhibited platelet aggregation and reduced platelet ATP and $\beta$-TG release from WPS of non-pregnant women in a dose-dependent manner, following stimulation with ADP $(0.5-1.5 \mu \mathrm{M})$, or collagen $(0.5-1.25 \mu \mathrm{g} / \mathrm{mL})$. Taurine's antiaggregant effect paralleled with the increase of taurine concentration in platelets. A similar dose-dependent inhibition of platelet aggregation has been noted after triggering taurine-loaded WPS from non-pregnant women with $1 \mu \mathrm{M}$ A23187 (a calcium ionophore). However, no effect of taurine in any doses on A23187-induced platelet aggregation has been registered following EDTA addition [154]. As A23187 is a non-physiological agonist able to increase platelet $\mathrm{Ca}^{2+}$ influx by changing membrane permeability [155], the lack of taurine's effect on A23187-induced aggregation after EDTA addition made the authors assume that taurine might downregulate platelet $\mathrm{Ca}^{2+}$ influx [154]. This finding is in accordance with data reported by Atahanov et al. in the same year, with taurine $(0.01 \mathrm{~mol} / \mathrm{l})$ being proven to blunt the in vitro platelet calcium response to PAF [156]. Overall, this study concluded that an increased capacity of platelets to uptake taurine in severe EPH gestosis may lead to a decrease in platelet aggregation, by reducing $\mathrm{Ca}^{2+}$ influx and diminishing platelets release response to agonists. However, 
caution is needed in drawing this conclusion. Decrease of aggregation in EPH gestosis may be also attributed to a refractory state (desensitization) of platelets, following their activation [152]. Therefore, the role of taurine in counterbalancing the hypercoagulative state associated to severe EPH gestosis remains to be reconsidered [154].

In another in vitro study, Miglis et al. showed that taurine at different concentrations (varying between 5 and $25 \mathrm{mM}$ ) suppressed to the same degree (10\%) platelet aggregation induced by thrombin $(1.0 \mathrm{U} / \mathrm{mL})$, in PRP from healthy volunteers. No significant differences between taurine and control groups have been found when the extent of ADP (0.02 mM)-induced platelet shape change (ESC) was assessed. Moreover, only a slight tendency to decrease (but without reaching statistical significance) maximal clot strength and stability was registered when a thromboelastographic experiment (triggered by $0.6 \mathrm{U} / \mathrm{mL}$ thrombin and $6.25 \mathrm{mM} \mathrm{CaCl}_{2}$ ) was performed. Regarding the differences of the recorded results, the author speculated that ADP-induced aggregation is known to use other platelet receptors than ESC triggered by ADP. In addition, a 10\% magnitude change of platelet aggregation generated by taurine may not be strong enough to induce a significant change in the overall clot strength measured by TEG. Moreover, the effect of $\mathrm{Ca}^{2+}$ added to initiate TEG testing may overcome the inhibitory effect of taurine on platelet activity [119].

The same beneficial effect of taurine on platelet aggregation was proven individually or in combination with caffeine in an in vitro study on PRP from healthy donors, suggesting that low concentrations of these compounds (lower than those usually found in energy drinks), may have a synergistic effect in reducing platelet activity [157].

In 1997 and 1998, Roshchupkin and collaborators published several studies regarding the antiplatelet action of chloramine derivatives, such as DT [158-161]. DT was shown to inhibit platelet-dense granule secretion, suppress spontaneous and induced aggregation, induce disaggregation of aggregated platelets, and exert systemic antithrombotic effects [158-161]. Additionally, DT elicited similar efficacy as acetylsalicylic acid (ASA) and ticlopidine in inhibiting secondary platelet aggregation, and even more potency than those drugs in suppressing primary platelet aggregation [158]. More recently, Murina et al. showed that taurine alone in a concentration of $10 \mathrm{mM}$ failed to change platelet aggregation in PRP from healthy donors, while in combination with $1 \mathrm{mM}$ sodium hypochlorite $(\mathrm{NaOCl})$ it potentiated the antiaggregant effect of $\mathrm{NaOCl}$ by 1.7 times, following stimulation with $10 \mu \mathrm{M}$ ADP. Further, incubation of PRP with DT $(0.25 \mathrm{mM})$ inhibited platelet aggregation to the same extent as $1 \mathrm{mM} \mathrm{NaOCl}$ [136]. Another finding of this study, obtained from experiments not performed on humans but on animals (rabbit PRP), showed that biogenic chloramines are able to elicit a high initial selectivity for platelet surface binding (result expressed as a higher rate constant of chloramines interaction with platelet receptors, than that achieved when attaching to plasma proteins receptors) [136]. The pronounced antiaggregant effect of DT described in these studies performed by Murina and collaborators [135,136,158-161], the apparent safety of its therapeutic doses [136], the high stability during a long-term period of storage ( 4 months), and the notable selectivity in reaction with platelets, led the authors suggest that there are good grounds to believe that DT could be an adjuvant drug in future antiplatelet therapy [136].

Overall, although human studies describing the effect of taurine and its derivatives on platelet function bring less information than animal experiments, they are consistent with them and provide additional insights into their mechanisms of action, thus contributing to a broader picture of their beneficial effects. 
Table 1. The characteristics of included animal studies.

\begin{tabular}{|c|c|c|c|c|c|}
\hline Reference & $\begin{array}{c}\text { Animal Subjects, Sex, Number } \\
\text { of Animals per Group, Type of } \\
\text { Experiment }\end{array}$ & $\begin{array}{c}\text { Taurine or } \\
\text { Related Compounds }\end{array}$ & $\begin{array}{l}\text { Design of the Study (Taurine } \\
\text { Dose, Time of Administration) }\end{array}$ & $\begin{array}{c}\text { Platelet Aggregation Variation } \\
\text { (Agonist) }\end{array}$ & $\begin{array}{l}\text { Outcome from Other Assays of } \\
\text { Platelet Function (Agonist), or from } \\
\text { Animal Models of Thrombosis }\end{array}$ \\
\hline Kurachi, M. et al., 1987 [126] & Guinea pigs, in vitro & Taurine & $\begin{array}{l}40 \mathrm{nM}, 2 \text { min before adding the } \\
\text { agonist }\end{array}$ & $\downarrow$ (PAF) & \\
\hline Hayes, KC. et al., 1989 [114] & $\begin{array}{l}\text { Cats, males and females with } \\
\text { equal distribution, } n=6 \text {, ex vivo }\end{array}$ & Taurine & $\begin{array}{l}0.5 \mathrm{~g} \mathrm{~T} / \mathrm{kg} \text { diet (from the time of } \\
\text { weaning to the age of } \\
10-24 \text { months) }\end{array}$ & $\begin{array}{l}\downarrow\left(\uparrow \mathrm{PA}_{\mathrm{t}} \text { by } 140 \% \text { in } \mathrm{T} \text {-supplemented }\right. \\
\text { vs. T-deficient cats, when triggered } \\
\text { with collagen) }\end{array}$ & $\begin{array}{l}\uparrow \text { of platelet GSH concentration by } 53 \% \\
\text { in T-supplemented vs. T-deficient cats }\end{array}$ \\
\hline Ji, Y. et al., 1995 [131] & Rats (2k1c), $n=6$, ex vivo & Taurine & $30 \mathrm{mg} / \mathrm{kg} /$ day, for 9 weeks & $\begin{array}{ll}- & \downarrow \text { from } 95.95 \pm 2.13 \text { (C group) } \\
& \text { to } 87.63 \pm 4.47 \text { (T group) (ADP, } \\
& 4 \mu \mathrm{mol} / \mathrm{L} \text { ) } \\
- & \downarrow \text { from } 88.22 \pm 3.81(\mathrm{C}) \text { to } 74.92 \\
& \pm 7.56(\mathrm{~T}) \text { (thrombin, } 4 \mathrm{U} / \mathrm{mL})\end{array}$ & \\
\hline \multirow[b]{2}{*}{ Huang, HL. et al., 1995 [41] } & Rats, $n=6$, in vivo & Taurine & $100 \mathrm{mg} / \mathrm{kg}$ & & $\begin{array}{l}\downarrow \text { of thrombosis wet weight by a rate of } \\
47.82 \% \text {, vs. controls }\end{array}$ \\
\hline & Rats, $n=6$, ex vivo & Taurine & $100 \mathrm{mg} / \mathrm{kg}$ & $\begin{array}{ll}- & \downarrow \text { by a rate of } 37.40 \% \text { (T vs. C } \\
\text { group) (ADP, } 2 \mu \mathrm{mol} / \mathrm{L}) & \downarrow \text { by a rate of } 44.41 \% \text { (T vs. C } \\
& \text { group) (collagen, } 0.05 \mathrm{~mL} / \mathrm{mL} \\
& \text { PRP) } \\
- & \downarrow \text { by a rate of } 37.87 \% \text { (T vs. C } \\
\text { group) (thrombin, } 1 \mathrm{U} / \mathrm{mL})\end{array}$ & $\downarrow$ platelet $\mathrm{Tx} \mathrm{A}_{2}$ release (ADP) \\
\hline Park, IS. et al., 2007 [132] & Rats, $n=10$, ex vivo & Taurine & $5 \%$ in diet, for 4 weeks & $\begin{array}{ll}- & \downarrow \text { MAgr from } 19.46 \pm 3.20 \text { to } \\
14.36 \pm 1.85 \text { (T vs. C group) } \\
\text { (ADP, } 2 \mu \mathrm{M}) \\
\downarrow \text { MAgr from } 17.13 \pm 3.72 \text { to } \\
\text { 14.20 } \pm 3.06 \text { (Ch. }+ \text { T group vs. } \\
\text { Ch. alone fed group of rats) } \\
\text { (ADP, } 2 \mu \mathrm{M})\end{array}$ & \\
\hline Roşca, A. et al., 2013 [133] & Rats, males, $n=10$, ex vivo & Taurine & $\begin{array}{l}2 \% \text { in drinking water, for } 3 \\
\text { months }\end{array}$ & $\downarrow(\mathrm{ADP}, 2.5 \mu \mathrm{M})$ & \\
\hline Roşca, A. et al., 2013 [134] & Rats, males, $n=10$, ex vivo & Taurine & $\begin{array}{l}2 \% \text { in drinking water, for } 3 \\
\text { months }\end{array}$ & & N outcome for MA measured by TEG \\
\hline
\end{tabular}


Table 1. Cont.

\begin{tabular}{|c|c|c|c|c|c|}
\hline Reference & $\begin{array}{c}\text { Animal Subjects, Sex, Number } \\
\text { of Animals per Group, Type of } \\
\text { Experiment }\end{array}$ & $\begin{array}{c}\text { Taurine or } \\
\text { Related Compounds }\end{array}$ & $\begin{array}{l}\text { Design of the Study (Taurine } \\
\text { Dose, Time of Administration) }\end{array}$ & $\begin{array}{c}\text { Platelet Aggregation Variation } \\
\text { (Agonist) }\end{array}$ & $\begin{array}{l}\text { Outcome from Other Assays of } \\
\text { Platelet Function (Agonist), or from } \\
\text { Animal Models of Thrombosis }\end{array}$ \\
\hline \multirow[t]{2}{*}{ Murina, M.A. et al., 2002 [135] } & Mice, in vivo & DT & $\begin{array}{ll}- & 3.4-6.8 \mathrm{mg} / \mathrm{kg} \\
- & 6.8 \mathrm{mg} / \mathrm{kg}\end{array}$ & & $\begin{array}{ll}\text { - } & \downarrow \text { mortality rate from } 96 \% \text { in } \\
\text { controls to up to } 10 \% \text { in DT } \\
\text { group (ADP, } 300 \mathrm{mg} / \mathrm{kg} \text { ) } \\
\uparrow \text { survival rate from } 16 \% \text { in } \\
\text { controls to } 64 \% \text { in DT group } \\
\text { (administered mixture: } 15 \mathrm{mg} / \mathrm{kg} \\
\text { collagen and } 8.6 \mathrm{mg} / \mathrm{kg} \\
\text { epinephrine) }\end{array}$ \\
\hline & Mice, male, ex vivo & DT & $6.8 \mathrm{mg} / \mathrm{kg}$, i.v & $\begin{array}{l}\downarrow \text { by a rate of } 50 \% \text { (DT vs. C group) } \\
(\mathrm{ADP}, 10 \mu \mathrm{M})\end{array}$ & \\
\hline \multirow[b]{2}{*}{ Murina, M.A. et al., 2007 [136] } & Rabbits, in vitro & DT & $10 \mu \mathrm{M}$ & $\downarrow$ I $_{\text {SALS }}$ by half (ADP, $\left.0.2 \mu \mathrm{M}\right)$ & \\
\hline & Rabbits, in vitro & DT & 10 millimoles / $\mathrm{L}$ & $\begin{array}{l}\downarrow \text { markedly the impedance measured } \\
\text { by whole blood aggregometry (ADP, } \\
10 \mu \mathrm{M} \text { ) }\end{array}$ & \\
\hline Kaptanoglu, L. et al., 2008 [44] & Rat, $n=10$, in vivo & $\mathrm{TL}$ & $\begin{array}{l}10 \mathrm{mg} \text {, or } 20 \mathrm{mg} \text {, i.v; } \\
\text { Heparin }(100 \mathrm{antiXa} \\
\mathrm{ICU} / 2 \mathrm{~mL} / \mathrm{kg} \text {, nadroparin } \\
\text { calcium) }\end{array}$ & & $\begin{array}{l}\downarrow \text { of thrombus weight by a rate of } 42 \% \\
\text { vs. C (but significantly higher than that } \\
\text { in heparin treated group). }\end{array}$ \\
\hline Murina, M.A. et al., 2009 [137] & Rabbits, in vitro & $\begin{array}{ll}- & \mathrm{DT} \\
- & \mathrm{CT}, \text { or } \mathrm{CMT}\end{array}$ & $\begin{array}{ll}- & 0.2 \mathrm{mM} \\
- & 0.5 \mathrm{mM}\end{array}$ & $\begin{array}{ll}- & \downarrow \text { I } \\
- & \downarrow \mathrm{I}_{\text {SALS }} \text { by } 50 \%(\text { ADP, } 10 \mu \mathrm{M}) \\
\text { (ADP, } 10 \mu \mathrm{M})\end{array}$ & \\
\hline Murina, M.A. et al., 2014 [139] & Rabbits, in vitro & $\begin{array}{ll}- & \text { PCT } \\
- & \text { IPCT }\end{array}$ & $\begin{array}{ll}- & 1 \mathrm{mM} \\
- & 1 \mathrm{mM}\end{array}$ & $\begin{array}{ll}- & \downarrow \text { to } 38 \pm 4.1 \% \text { vs. baseline } \\
& (100 \%)(\mathrm{ADP}, 10 \mu \mathrm{M}) \\
- & \downarrow \text { to } 60 \pm 4.2 \% \text { vs. baseline } \\
& (100 \%)(\mathrm{ADP}, 10 \mu \mathrm{M})\end{array}$ & \\
\hline
\end{tabular}

Abbreviations: PAF—platelet aggregating factor; $n$-number of subjects per group; T—taurine; $\mathrm{PA}_{\mathrm{t}}$ — the amount in $\mu \mathrm{g}$ of agonist required to elicit $10 \%$ of a predetermined maximal aggregation in $1 \mathrm{~mL}$ PRP; PRP — platelet rich plasma; GSH—glutathione; 2k1c-two-kidney-one-clip Goldblatt renovascular hypertensive rats; $\mathrm{C}$-controls; $\mathrm{TxA} \mathrm{A}_{2}$-thromboxane $\mathrm{A}_{2} ; \mathrm{ADP}$ - adenosine diphosphate; MAgr - the maximum platelet aggregation at the point where aggregation dissociates; Ch.-cholesterol; MA—maximal clot strength and stability; TEG-Thromboelastography; DT-N,N-dichlorotaurine; ISALS - intensity of small-angle light scattering aggregation; CT-N-chlorotaurine; CMT-N-chloro-N-methyltaurine; TL-Taurolidine; PCT—N-propionyl-N-chlorotaurine; IPCT—N-isopropyl-N-chlorotaurine; $\uparrow$ - up regulation; $\downarrow-$ down-regulation; $\mathrm{N} —$ neutral effect. 
Table 2. The characteristics of included human studies.

\begin{tabular}{|c|c|c|c|c|c|}
\hline Reference & $\begin{array}{c}\text { Human Subjects, Sex, } \\
\text { Number of Individuals per } \\
\text { Group, Type of Experiment }\end{array}$ & $\begin{array}{l}\text { Taurine or Related } \\
\text { Compounds }\end{array}$ & $\begin{array}{l}\text { Design of the Study } \\
\text { (Taurine Dose, Time of } \\
\text { Administration) }\end{array}$ & $\begin{array}{c}\text { Platelet Aggregation Variation } \\
\text { (Agonist) }\end{array}$ & $\begin{array}{l}\text { Outcome from Other Assays } \\
\text { of Platelet Function (Agonist) }\end{array}$ \\
\hline \multirow[b]{2}{*}{ Almazov, V.A. et al., 1985 [140] } & Human platelets, $n=10$, in vitro & Taurine & $25 \mathrm{nM}$ & $\downarrow$ by half $(\mathrm{ADP}-3.5 \mu \mathrm{M})$ & \\
\hline & Human platelets, $n=5$, in vitro & Taurine & $25 \mathrm{nM}$ & & $\begin{array}{l}\uparrow \text { of platelet } \mathrm{Ca}, \mathrm{Mg} \text {-ATPase activity by } \\
45 \%\end{array}$ \\
\hline \multirow{2}{*}{ Hayes, K.C. et al., 1989 [113] } & $\begin{array}{l}\text { Healthy volunteers, male, } n=5 \text {, } \\
\text { ex vivo }\end{array}$ & Taurine & $400 \mathrm{mg} /$ day, for 8 days & $\begin{array}{l}\downarrow \text { ( } \uparrow \mathrm{PA}_{\mathrm{t}} \text { by } 25 \% \text { in } \mathrm{T} \text { group vs. } \\
\text { controls, when triggered with } \\
\text { collagen) }\end{array}$ & $\uparrow$ of platelet GSH concentration by $34 \%$ \\
\hline & $\begin{array}{l}\text { Healthy volunteers, male, } n=5 \text {, } \\
\text { ex vivo }\end{array}$ & Taurine & $1600 \mathrm{mg} /$ day, for 8 days & $\begin{array}{l}\downarrow \text { ( } \uparrow \mathrm{PA}_{\mathrm{t}} \text { by } 72 \% \text { in } \mathrm{T} \text { group vs. } \\
\text { controls, when triggered with } \\
\text { collagen) }\end{array}$ & $\begin{array}{l}\downarrow \text { platelet } \mathrm{TxB}_{2} \text { release (collagen, } 0.93 \\
\mu \mathrm{g})\end{array}$ \\
\hline \multirow{2}{*}{$\begin{array}{l}\text { Franconi, F. et al., } 1994 \text { [145] and } \\
\text { Franconi F. et al., } 1995 \text { [146] }\end{array}$} & 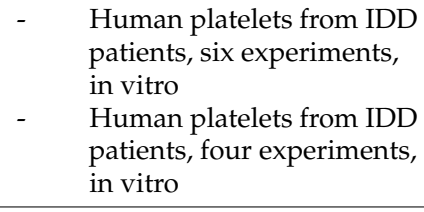 & Taurine & $\begin{array}{ll}- & 10 \mathrm{mM} \\
- & \text { increasing dose }\left(10^{-6},\right. \\
& \left.10^{-5}, \text { or } 10^{-2} \mathrm{~mol} / \mathrm{L}\right)\end{array}$ & $\begin{array}{ll}\text { - } & \downarrow \text { (arach. ac, various } \\
& \text { concentrations-from } 0.2 \text { to } 1 \\
\mathrm{mM}) & \\
\text { - } \quad & \downarrow \text { (arach. ac, } 0.6 \mathrm{mmol} / \mathrm{L})\end{array}$ & \\
\hline & $\begin{array}{ll}\text { - } & \text { IDD patients, } n=17, \mathrm{ex} \\
& \text { vivo } \\
\text { - } & \text { IDD patients, } n=35, \mathrm{ex} \\
& \text { vivo }\end{array}$ & Taurine & $1.5 \mathrm{~g} /$ day, for 3 months & $\begin{array}{ll}- & \downarrow\left(\uparrow E D_{50}, \text { from } 0.44 \pm 0.07\right. \\
& \mathrm{mmol} / \mathrm{L} \text { to } 0.72 \pm 0.04 \\
\mathrm{mmol} / \mathrm{L} \text { arach. ac }) \\
\text { - } \quad \downarrow \text { (arach. ac, various } \\
\text { concentration-up to } 1 \\
\mathrm{mmol} / \mathrm{L})\end{array}$ & \\
\hline Spohr, C. et al., 2005 [118] & $\begin{array}{l}\text { Men with predisposition to type } \\
\text { II diabetes mellitus, } n=9 \text {, ex vivo }\end{array}$ & Taurine & $\begin{array}{l}1.5 \mathrm{~g} / \text { day, for two 8-week } \\
\text { periods (separated by } 2 \text { weeks of } \\
\text { washout) }\end{array}$ & $\begin{array}{l}\mathrm{N} \text { outcome (TC: } 3.86 \pm 3.25 \mu \mathrm{mol} / 1 \\
\text { for T group; } 3.86 \pm 2.21 \mu \mathrm{mol} / 1 \text { for } \\
\text { placebo group) }\end{array}$ & \\
\hline
\end{tabular}


Table 2. Cont.

\begin{tabular}{|c|c|c|c|c|c|}
\hline Reference & $\begin{array}{c}\text { Human Subjects, Sex, } \\
\text { Number of Individuals per } \\
\text { Group, Type of Experiment }\end{array}$ & $\begin{array}{l}\text { Taurine or Related } \\
\text { Compounds }\end{array}$ & $\begin{array}{l}\text { Design of the Study } \\
\text { (Taurine Dose, Time of } \\
\text { Administration) }\end{array}$ & $\begin{array}{c}\text { Platelet Aggregation Variation } \\
\text { (Agonist) }\end{array}$ & $\begin{array}{l}\text { Outcome from Other Assays } \\
\text { of Platelet Function (Agonist) }\end{array}$ \\
\hline \multirow[t]{2}{*}{ Namba, K. et al., 1992 [154] } & $\begin{array}{l}\text { Human platelets from } \\
\text { non-pregnant women, } n=5,10 \\
\text { experiments, in vitro }\end{array}$ & Taurine & $\begin{array}{l}\text { increasing dose }(6.25,25 \text {, or } 50 \\
\mathrm{mM})\end{array}$ & $\begin{array}{l}\downarrow \text { with } 25.6 \% \text { to } 42.4 \% \text { (ADP, } 0.5-1.5 \mu \mathrm{M} \text { ), } \\
\text { and with } 29.5 \% \text { to } 36.7 \% \text { (collagen, } \\
0.5-1.25 \mu \mathrm{g} / \mathrm{mL} \text { ) }\end{array}$ & $\begin{array}{ll} & \downarrow \text { ATP release response with } \\
29.2 \% \text { to } 61.1 \% \text {-triggered by } \\
\text { ADP }(0.5-1.5 \mu \mathrm{M}) \text {, and with } \\
54.5 \% \text { to } 57.9 \% \text { - triggered by } \\
\text { collagen }(0.5-1.25 \mu \mathrm{g} / \mathrm{mL}) \\
\downarrow \beta-\mathrm{TG} \text { release response with } \\
21.8 \% \text { to } 48.1 \% \text { - triggered by } \\
\text { ADP }(0.5-1.5 \mu \mathrm{M}), \text { and with } \\
29.9 \% \text { to } 41.2 \% \text { - triggered by } \\
\text { collagen }(0.5-1.25 \mu \mathrm{g} / \mathrm{mL})\end{array}$ \\
\hline & $\begin{array}{l}\text { Human platelets from } \\
\text { non-pregnant women, } n=5,5 \\
\text { experiments, in vitro }\end{array}$ & Taurine & $\begin{array}{l}\text { increasing dose }(6.25,25, \text { or } 50 \\
\mathrm{mM})\end{array}$ & $\begin{array}{l}\downarrow-\downarrow \text { with } 46 \% \text { to } 69.4 \% \text { (A23187, } \\
1 \mu \mathrm{M}) \\
\text { - } \\
\text { foutcome (A23187, } 1 \mu \mathrm{M}, \\
\text { following } 1 \mathrm{mM} \text { EDTA addition) }\end{array}$ & \\
\hline \multirow[b]{2}{*}{ Miglis, M. et al., 2002 [119] } & $\begin{array}{l}\text { Human platelets, } 5 \text { different } \\
\text { donors, in vitro }\end{array}$ & Taurine & increasing dose ( 5 to $25 \mathrm{mM}$ ) & $\begin{array}{l}\downarrow \text { by } 10 \% \text {, for each } \mathrm{T} \text { dose (thrombin, } 1.0 \\
\mathrm{U} / \mathrm{mL} \text { ) }\end{array}$ & \\
\hline & $\begin{array}{l}\text { Human platelets, } 5 \text { different } \\
\text { donors, in vitro }\end{array}$ & Taurine & 5 or $25 \mathrm{mM}$ & & N outcome for ESC (0.02 mM ADP) \\
\hline \multirow{3}{*}{ Murina, M.A. et al., 2007 [136] } & $\begin{array}{l}\text { Platelets from healthy donors, } \\
\text { in vitro }\end{array}$ & Taurine & $10 \mathrm{mM}$ & N outcome (ADP, $10 \mu \mathrm{M})$ & \\
\hline & $\begin{array}{l}\text { Platelets from healthy donors, } \\
\text { in vitro }\end{array}$ & Taurine and $\mathrm{NaOCl}$ & $10 \mathrm{mM}$ and $1 \mathrm{mM}$, respectively & $\begin{array}{l}\downarrow(\uparrow \mathrm{MI} \text { by } 1.7 \text { times in the mixed treated } \\
\text { vs. NaOCl alone group) (ADP, } 10 \mu \mathrm{M})\end{array}$ & \\
\hline & $\begin{array}{l}\text { Platelets from healthy donors, } \\
\text { in vitro }\end{array}$ & DT & $0.25 \mathrm{mM}$ & $\downarrow(\uparrow \mathrm{MI}$ to $40 \pm 7)(\mathrm{ADP}, 10 \mu \mathrm{M})$ & \\
\hline
\end{tabular}

Abbreviations: $n$-number of subjects per group; ADP—adenosine diphosphate; Ca, Mg-ATPase—calcium, magnesium ATPase; $\mathrm{PA}_{\mathrm{t}}$-the amount in $\mu g$ of agonist required to elicit $10 \%$ of a predetermined maximal aggregation in $1 \mathrm{~mL}$ PRP; GSH—glutathione; $\mathrm{TxB}_{2}$-thromboxane $\mathrm{B}_{2} ; \mathrm{IDD}$-insulin-dependent diabetes mellitus; arach. ac-arachidonic acid $\mathrm{ED}_{50}$ - effective dose 50, or the amount of agonist necessary to reach the $50 \%$ magnitude of maximal aggregation; PRP-platelet-rich plasma; PPP-platelet-poor plasma; TC-the threshold concentration, or the lowest concentration in $\mu \mathrm{mol} / 1$ of ADP required to elicit irreversible aggregation (with a difference of at least $80 \%$ in light transmission between PRP and change; MA—maximal clot strength and stability; TEG—-thromboelastography; NaOCl—sodium hypochlorite; vs —versus; MI—magnitude of agoregation inhibition, standardized to control; $\uparrow$-up regulation; $\downarrow$-down-regulation; $\mathrm{N}$-neutral effect. 
Still far from being elucidated, the potential mechanisms underlying the overall inhibitory influence of taurine and its derivatives on platelet activity can be summarized as follows: decreased platelet $\mathrm{TxA}_{2}$ [41] and $\mathrm{TxB}_{2}$ production [113]; suppression of platelet cyclooxygenase activity [144,158]; stimulation of calmodulin-mediated platelet $\mathrm{Ca}, \mathrm{Mg}$ ATPase activity [140,162], attenuation of platelet $\mathrm{Ca}^{2+}$ influx [141,154] and suppression of intraplatelet $\mathrm{Ca}^{2+}$ response to activating agonists [156]; platelet stabilization against PAF $[126,143,156]$; suppression of $\beta$-TG and ATP release response to agonists, as markers of discharge from alpha and dense platelet granules [154]; preservation of platelet glutathione pool [113]; increased affinity of covalent inhibitors (e.g., DT, PCT, IPCT) to molecular targets, i.e., sulfur-containing groups on platelet surface (such might be the thiol group of $\mathrm{P}_{2} \mathrm{Y}_{12}$ ADP receptor) [135-139]; and pronounced enhancement of hydrogen sulfide $\left(\mathrm{H}_{2} \mathrm{~S}\right)$ plasma level [163-166], $\mathrm{H}_{2} \mathrm{~S}$ being known to inhibit platelet activation and aggregation [167-172]. Taurine may also interfere with platelet activity by generating complementary processes such as an increase of the endothelial NO release [173-176], decrease of epinephrine and norepinephrine circulant level [177-179], suppression of CD147-dependent MMP-9 pathway on ischemic brain endothelium [54], reduction of serum $\mathrm{TxB}_{2}$ [175], decrease of $\mathrm{TxA}_{2}$ and $\mathrm{TxB}_{2}$ release from various organs [127,180-183], while increasing $\mathrm{PgI}_{2}$ production $[127,183]$. Through all these mentioned pathways taurine and its derivatives are thought to render platelets more stable against a large variety of aggregating agonists, both physiological (ADP, thrombin, collagen, epinephrine, and others) $[113,119,132,146]$ or non-physiological (e.g., A23187) [154].

\section{Concluding Remarks}

Based on a critical analysis of all existing data, we can conclude that there are good reasons to believe that taurine and its derivatives should receive more attention from the scientific world for their inhibitory action on platelet activity and their possible antithrombotic potential. In vivo, ex vivo and in vitro animal or human studies have provided complementary information and succeeded into shaping taurine and its analogues' antiplatelet profile to a certain extent. However, caution is needed when promoting bold conclusions, as there are some important study limitations, mainly related to their experimental design, statistical power, or the relative scarcity of the presented mechanisms. The heterogenicity of the assays, treatment protocols, or study populations makes data analysis and pooling difficult. More comprehensive animal outcomes are certainly needed, to validate the existing findings and to give new perspectives on intimate mechanisms, before extrapolated to humans. However, there is one limitation that seems to be very difficult to cross, and that is carrying out prospective human studies on thrombosis outcome. Taurine-mediated protection against pathologies associating thrombotic diathesis, such as diabetes, traumatic brain injury, or acute ischemic stroke represents an argument that encourages further research of this fascinating nutrient, that seemingly displays permissible side effects. Nowadays, taurine is approved in Japan as a therapeutic agent for heart failure treatment, and only the lack of large-scale phase 3 clinical trials restricts taurine use as a therapeutic agent in several other pathologies for the treatment of which it has been shown to be effective (hypertension, atherosclerosis, stroke, neurodegenerative diseases, metabolic diseases, e.g., diabetes mellitus, and others). The discovery of taurine derivatives with higher stability and selectivity for sulfhydryl groups on platelet surface (e.g., DT or amido-derivatives), is another valuable step, which may be followed in the next years by the synthesis of new taurine chloramines with more specificity for the reactive sulfur-containing chemical groups on platelets, such as those found on ADP, collagen, or glycoprotein IIb/IIIa receptors. Searching for new, alternative antithrombotic drugs with minimal side effects (i.e., low risk of bleeding), and with a long-term inhibition on platelet activity (conferring the possibility of low dose administration), is probably currently the main goal in this area of interest. The question remains whether taurine, this semi-essential, commonly found, and highly beneficial amino acid (or its derivatives) will be able to face this challenge in the future. We shall see. 
Author Contributions: Conceptualization, A.E.R.; writing-original draft preparation, A.E.R., R.M., C.-M.A.-T., A.M., S.E.V., S..G., M.O., I.I.; writing-review and editing, all authors; visualization, A.E.R., A.-M.V., C.C., B.O.P.; supervision, B.O.P. and L.Z. All authors have read and agreed to the published version of the manuscript.

Funding: This research received no external funding.

Conflicts of Interest: The authors declare no conflict of interest. The funders had no role in the design of the study; in the collection, analyses, or interpretation of data; in the writing of the manuscript, or in the decision to publish the results.

\section{References}

1. Jacobsen, J.G.; Smith, L.H. Biochemistry and physiology of taurine and taurine derivatives. Physiol. Rev. 1968, $48,424-511$. [CrossRef] [PubMed]

2. Huxtable, R.J. Physiological actions of taurine. Physiol. Rev. 1992, 72, 101-163. [CrossRef] [PubMed]

3. Lambert, I.H.; Kristensen, D.M.; Holm, J.B.; Mortensen, O.H. Physiological role of taurine-From organism to organelle. Acta Physiol. 2015, 213, 191-212. [CrossRef] [PubMed]

4. Schaffer, S.W.; Jong, C.J.; Ramila, K.C.; Azuma, J. Physiological roles of taurine in heart and muscle. J. Biomed. Sci. 2010, 17 (Suppl. 1), S2. [CrossRef]

5. Xu, Y.J.; Arneja, A.S.; Tappia, P.S.; Dhalla, N.S. The potential health benefits of taurine in cardiovascular disease. Exp. Clin. Cardiol. 2008, 13, 57-65.

6. Ripps, H.; Shen, W. Review: Taurine: A "very essential" amino acid. Mol. Vis. 2012, 18, 2673-2686.

7. Clauson, K.A.; Shields, K.M.; McQueen, C.E.; Persad, N. Safety issues associated with commercially available energy drinks. J. Am. Pharm. Assoc. 2008, 48, e55-e63, quiz e64-7. [CrossRef]

8. Schaffer, S.W.; Shimada, K.; Jong, C.J.; Ito, T.; Azuma, J.; Takahashi, K. Effect of taurine and potential interactions with caffeine on cardiovascular function. Amino Acids 2014, 46, 1147-1157. [CrossRef]

9. Collard, J.M.; Sansonetti, P.; Papon, N. Taurine Makes Our Microbiota Stronger. Trends Endocrinol. Metab. 2021, 32, $259-261$. [CrossRef]

10. Rosca, A.E.; Iesanu, M.I.; Zahiu, C.D.M.; Voiculescu, S.E.; Paslaru, A.C.; Zagrean, A.M. Capsaicin and Gut Microbiota in Health and Disease. Molecules 2020, 25, 5681. [CrossRef]

11. Schaffer, S.; Kim, H.W. Effects and Mechanisms of Taurine as a Therapeutic Agent. Biomol. Ther. 2018, 26, 225-241. [CrossRef] [PubMed]

12. Marcinkiewicz, J.; Kontny, E. Taurine and inflammatory diseases. Amino Acids 2012, 32, 143. [CrossRef] [PubMed]

13. Schaffer, S.W.; Ito, T.; Azuma, J. Clinical significance of taurine. Amino Acids 2014, 46, 1-5. [CrossRef] [PubMed]

14. Wójcik, O.P.; Koenig, K.L.; Zeleniuch-Jacquotte, A.; Costa, M.; Chen, Y. The potential protective effects of taurine on coronary heart disease. Atherosclerosis 2010, 208, 19-25. [CrossRef] [PubMed]

15. Zulli, A. Taurine in cardiovascular disease. Curr. Opin. Clin. Nutr. Metab. Care 2011, 14, 57-60. [CrossRef]

16. Roşca, A.E.; Vlădăreanu, A.-M.; Mititelu, A.; Popescu, B.O.; Badiu, C.; Căruntu, C.; Voiculescu, S.E.; Onisâi, M.; Gologan, Ş.; Mirica, R.; et al. Effects of Exogenous Androgens on Platelet Activity and Their Thrombogenic Potential in Supraphysiological Administration: A Literature Review. J. Clin. Med. 2021, 10, 147. [CrossRef]

17. Militante, J.D.; Lombardini, J.B. Treatment of hypertension with oral taurine: Experimental and clinical studies. Amino Acids 2002, 23, 381-393. [CrossRef]

18. Abebe, W.; Mozaffari, M.S. Role of taurine in the vasculature: An overview of experimental and human studies. Am. J. Cardiovasc. Dis. 2011, 1, 293-311.

19. Roşca, A.; Stoian, I.; Badiu, C.; Gaman, L.; Popescu, B.; Iosif, L.; Mirica, R.; Tivig, I.; Stancu, C.; Căruntu, C.; et al. Impact of chronic administration of anabolic androgenic steroids and taurine on blood pressure in rats. Braz. J. Med Biol. Res. 2016, 49 , e5116. [CrossRef]

20. Waldron, M.; Patterson, S.D.; Tallent, J.; Jeffries, O. The Effects of Oral Taurine on Resting Blood Pressure in Humans: A Meta-Analysis. Curr. Hypertens. Rep. 2018, 20, 81. [CrossRef]

21. Pion, P.D.; Kittleson, M.D.; Thomas, W.P.; Delellis, L.A.; Rogers, Q.R. Response of cats with dilated cardiomyopathy to taurine supplementation. J. Am. Vet. Med Assoc. 1992, 201, 275-284. [PubMed]

22. Militante, J.D.; Lombardini, J.B.; Schaffer, S.W. The role of taurine in the pathogenesis of the cardiomyopathy of insulin-dependent diabetes mellitus. Cardiovasc. Res. 2000, 46, 393-402. [CrossRef]

23. Sanderson, S.L. Taurine and carnitine in canine cardiomyopathy. Vet. Clin. N. Am. Small Anim. Pract. 2006, 36, 1325-1343. [CrossRef] [PubMed]

24. Ito, T.; Kimura, Y.; Uozumi, Y.; Takai, M.; Muraoka, S.; Matsuda, T.; Ueki, K.; Yoshiyama, M.; Ikawa, M.; Okabe, M.; et al. Taurine depletion caused by knocking out the taurine transporter gene leads to cardiomyopathy with cardiac atrophy. J. Mol. Cell. Cardiol. 2008, 44, 927-937. [CrossRef] [PubMed] 
25. Ontiveros, E.S.; Whelchel, B.D.; Yu, J.; Kaplan, J.L.; Sharpe, A.N.; Fousse, S.L.; Crofton, A.E.; Fascetti, A.J.; Stern, J.A. Development of plasma and whole blood taurine reference ranges and identification of dietary features associated with taurine deficiency and dilated cardiomyopathy in golden retrievers: A prospective, observational study. PLoS ONE 2020, 15, e0233206. [CrossRef]

26. Ansar, M.; Ranza, E.; Shetty, M.; Paracha, S.A.; Azam, M.; Kern, I.; Iwaszkiewicz, J.; Farooq, O.; Pournaras, C.J.; Malcles, A.; et al. Taurine treatment of retinal degeneration and cardiomyopathy in a consanguineous family with SLC6A6 taurine transporter deficiency. Hum. Mol. Genet. 2020, 29, 618-623. [CrossRef]

27. Schaffer, S.W.; Jong, C.J.; Ito, T.; Azuma, J. Effect of taurine on ischemia-reperfusion injury. Amino Acids 2012, 46, 21-30. [CrossRef]

28. Lourenço, R.; Camilo, M.E. Taurine: A conditionally essential amino acid in humans? An overview in health and disease. Nutr. Hosp. 2002, 17, 262-270.

29. Eby, G.; Halcomb, W.W. Elimination of Cardiac Arrhythmias Using Oral Taurine With L-Arginine With Case Histories: Hypothesis for Nitric Oxide Stabilization of the Sinus Node. Med. Hypotheses 2006, 6, 1200-1204. [CrossRef]

30. Krylova, I.B.; Bul'On, V.V.; Selina, E.N.; Sapronov, N.S.; Shabanov, P.D. Antiarrhythmic Activity of Taurepar during Ischemic and Reperfusion Damage to Myocardium. Bull. Exp. Biol. Med. 2015, 160, 228-230. [CrossRef]

31. Yang, Q.; Lv, Q.; Feng, M.; Liu, M.; Feng, Y.; Lin, S.; Yang, J.; Hu, J. Taurine Prevents the Electrical Remodeling in Ach-CaCl2 Induced Atrial Fibrillation in Rats. Adv. Exp. Med. Biol. 2017, 975, 821-830. [CrossRef] [PubMed]

32. Adameova, A.; Tappia, P.S.; Hatala, R.; Dhalla, N.S. Potential of Sulphur-containing Amino Acids in the Prevention of Catecholamine-induced Arrhythmias. Curr. Med. Chem. 2018, 25, 346-354. [CrossRef] [PubMed]

33. Azuma, J.; Sawamura, A.; Awata, N. Usefulness of Taurine in Chronic Congestive Heart Failure and Its Prospective Application. Jpn. Circ. J. 1992, 56, 95-99. [CrossRef] [PubMed]

34. Shao, A.; Hathcock, J.N. Risk assessment for the amino acids taurine, l-glutamine and l-arginine. Regul. Toxicol. Pharmacol. 2008, 50, 376-399. [CrossRef] [PubMed]

35. Ahmadian, M.; Roshan, V.D.; Aslani, E.; Stannard, S.R. Taurine supplementation has anti-atherogenic and anti-inflammatory effects before and after incremental exercise in heart failure. Ther. Adv. Cardiovasc. Dis. 2017, 11, 185-194. [CrossRef] [PubMed]

36. Brøns, C.; Spohr, C.; Storgaard, H.; Dyerberg, J.; Vaag, A.A. Effect of taurine treatment on insulin secretion and action, and on serum lipid levels in overweight men with a genetic predisposition for type II diabetes mellitus. Eur. J. Clin. Nutr. 2004, 58, 1239-1247. [CrossRef] [PubMed]

37. Storey, K.; Storey, J.; Brooks, S.; Churchill, T.A.; Brooks, R.J. Hatchling turtles survive freezing during winter hibernation. Proc. Natl. Acad. Sci. USA 1988, 85, 8350-8354. [CrossRef]

38. Ahmad, N.; Dube, B.; Agarwal, G.P.; Dube, R.K. Comparative studies of blood coagulation in hibernating and non-hibernating frogs (Rana tigrina). Thromb. Haemost. 1979, 42, 959-964. [CrossRef]

39. Boral, M.C.; Deb, C. Seasonal changes in body fluids and haematology in toad Bufo melanostictus a poikilothermic cold torpor. Proc. Indian Natl. Sci. Acad. 1970, 36, 369-379.

40. Zain-ul-Abedin, M.; Katorski, B. Increased blood clotting time in a hibernating lizard. Can. J. Physiol. Pharmacol. 1966, 44, 505-507. [CrossRef]

41. Huang, H.L.; Rao, M.R. Effects of neferine and its combination with taurine on platelet aggregation and experimental thrombosis in rats. Yao Xue Xue Bao 1995, 30, 486-489. [PubMed]

42. Ding, W.; Li, D.; Zhang, J. Influences of taurine on thrombolysis. Zhonghua Nei Ke Za Zhi 1996, 35, 378-381. (In Chinese) [PubMed]

43. Murina, M.A.; Fesenko, O.D.; Sergienko, V.I.; Chudina, N.A.; Roshchupkin, D.I. Antithrombotic activity of N,N-dichlorotaurine on mouse model of thrombosis in vivo. Bull Exp. Biol. Med. 2002, 134, 36-38. [CrossRef] [PubMed]

44. Kaptanoglu, L.; Kucuk, H.F.; Colak, E.; Kurt, N.; Bingul, S.M.; Akyol, H.; Torlak, O.A.; Yazici, F. The effect of taurolidine on experimental thrombus formation. Eur. J. Pharmacol. 2008, 578, 238-241. [CrossRef]

45. Jeynes, B.J. Combined streptokinase and taurochenodeoxycholate action on experimentally induced atherothromboemboli. Chandler Tube Study. Arch. Pathol. Lab. Med. 1986, 110, 1143-1148.

46. Jeynes, B.J. Treatment of experimentally induced cerebral atherothromboembolism in an animal model with streptokinase and taurochenodeoxycholate. Artery 1988, 15, 259-271.

47. Sun, M.; Xu, C. Neuroprotective Mechanism of Taurine due to Up-regulating Calpastatin and Down-regulating Calpain and Caspase-3 during Focal Cerebral Ischemia. Cell. Mol. Neurobiol. 2008, 28, 593-611. [CrossRef]

48. Sun, M.; Zhao, Y.; Gu, Y.; Xu, C. Anti-inflammatory mechanism of taurine against ischemic stroke is related to down-regulation of PARP and NF-kB. Amino Acids 2012, 42, 1735-1747. [CrossRef]

49. Guan, W.; Zhao, Y.; Xu, C. A Combined Treatment with Taurine and Intra-arterial Thrombolysis in an Embolic Model of Stroke in Rats: Increased Neuroprotective Efficacy and Extended Therapeutic Time Window. Transl. Stroke Res. 2011, 2, 80-91. [CrossRef]

50. Sun, M.; Zhao, Y.-M.; Gu, Y.; Xu, C. Therapeutic window of taurine against experimental stroke in rats. Transl. Res. 2012, 160, 223-229. [CrossRef]

51. Rukan, T.A.; Mksimovich, N.E.; Zimatkin, S.M. Morphofunctional state of vessel endothelium at the early stage of cerebral ischemia-reperfusion and the effect of taurin administration. Eksp. Klin. Farmakol. 2013, 76, 8-10. [PubMed]

52. Gharibani, P.M.; Modi, J.; Pan, C.; Menzie, J.; Ma, Z.; Chen, P.C.; Tao, R.; Prentice, H.; Wu, J.Y. The mechanism of taurine protection against endoplasmic reticulum stress in an animal stroke model of cerebral artery occlusion and stroke-related conditions in primary neuronal cell culture. Adv. Exp. Med. Biol. 2013, 776, 241-258. [CrossRef] [PubMed] 
53. Gharibani, P.; Modi, J.; Menzie, J.; Alexandrescu, A.; Ma, Z.; Tao, R.; Prentice, H.; Wu, J.Y. Comparison between single and combined post-treatment with S-Methyl-N,N-diethylthiolcarbamate sulfoxide and taurine following transient focal cerebral ischemia in rat brain. Neuroscience 2015, 300, 460-473. [CrossRef] [PubMed]

54. Jin, R.; Xiao, A.Y.; Liu, S.; Wang, M.; Li, G. Taurine Reduces tPA (Tissue-Type Plasminogen Activator)-Induced Hemorrhage and Microvascular Thrombosis After Embolic Stroke in Rat. Stroke 2018, 49, 1708-1718. [CrossRef]

55. Seizer, P.; Borst, O.; Langer, H.F.; Bültmann, A.; Münch, G.; Herouy, Y.; Stellos, K.; Krämer, B.; Bigalke, B.; Büchele, B.; et al. EMMPRIN (CD147) is a novel receptor for platelet GPVI and mediates platelet rolling via GPVI-EMMPRIN interaction. Thromb. Haemost. 2009, 101, 682-686. [CrossRef]

56. Seizer, P.; Ungern-Sternberg, S.N.; Schönberger, T.; Borst, O.; Münzer, P.; Schmidt, E.-M.; Mack, A.F.; Heinzmann, D.; Chatterjee, M.; Langer, H.; et al. Extracellular Cyclophilin A Activates Platelets Via EMMPRIN (CD147) and PI3K/Akt Signaling, Which Promotes Platelet Adhesion and Thrombus Formation In Vitro and In Vivo. Arter. Thromb. Vasc. Biol. 2015, 35, 655-663. [CrossRef]

57. Jin, R.; Xiao, A.Y.; Chen, R.; Granger, D.N.; Li, G. Inhibition of CD147 (Cluster of Differentiation 147) Ameliorates Acute Ischemic Stroke in Mice by Reducing Thromboinflammation. Stroke 2017, 48, 3356-3365. [CrossRef]

58. Ijiri, Y.; Ikarugi, H.; Tamura, Y.; Ura, M.; Morishita, M.; Hamada, A.; Mori, M.; Mori, H.; Yamori, Y.; Ishii, H.; et al. Antithrombotic effect of taurine in healthy Japanese people may be related to an increased endogenous thrombolytic activity. Thromb. Res. 2013, 131, 158-161. [CrossRef]

59. Yamori, Y.; Liu, L.; Ikeda, K.; Miura, A.; Mizushima, S.; Miki, T.; Nara, Y.; Who-Cardiovascular, O.B.O.T. Distribution of TwentyFour Hour Urinary Taurine Excretion and Association with Ischemic Heart Disease Mortality in 24 Populations of 16 Countries: Results from the WHO-CARDIAC Study. Hypertens. Res. 2001, 24, 453-457. [CrossRef]

60. Yamori, Y.; Liu, L.; Mori, M.; Sagara, M.; Murakami, S.; Nara, Y.; Mizushima, S. Taurine as the Nutritional Factor for the Longevity of the Japanese Revealed by a World-Wide Epidemiological Survey. Adv. Exp. Med. Biol. 2009, 643, 13-25. [CrossRef]

61. Yamori, Y.; Taguchi, T.; Mori, H.; Mori, M. Low cardiovascular risks in the middle aged males and females excreting greater 24-hour urinary taurine and magnesium in 41 WHO-CARDIAC study populations in the world. J. Biomed. Sci. 2010, 17, S21. [CrossRef] [PubMed]

62. Yamori, Y.; Taguchi, T.; Hamada, A.; Kunimasa, K.; Mori, H.; Mori, M. Taurine in health and diseases: Consistent evidence from experimental and epidemiological studies. J. Biomed. Sci. 2010, 17, S6. [CrossRef] [PubMed]

63. Sagara, M.; Murakami, S.; Mizushima, S.; Liu, L.; Mori, M.; Ikeda, K.; Nara, Y.; Yamori, Y. Taurine in 24-h Urine Samples Is Inversely Related to Cardiovascular Risks of Middle Aged Subjects in 50 Populations of the World. Adv. Exp. Med. Biol. 2015, 803, 623-636. [CrossRef]

64. Yamori, Y.; Sagara, M.; Arai, Y.; Kobayashi, H.; Kishimoto, K.; Matsuno, I.; Mori, H.; Mori, M. Soy and fish as features of the Japanese diet and cardiovascular disease risks. PLoS ONE 2017, 12, e0176039. [CrossRef]

65. Wu, F.; Koenig, K.L.; Zeleniuch-Jacquotte, A.; Jonas, S.; Afanasyeva, Y.; Wójcik, O.P.; Costa, M.; Chen, Y. Serum Taurine and Stroke Risk in Women: A Prospective, Nested Case-Control Study. PLoS ONE 2016, 11, e0149348. [CrossRef] [PubMed]

66. Bellentani, S.; Pecorari, M.; Cordonna, P.; Marchegiano, P.; Manenti, F.; Basisio, E.; Defabiani, E.; Galli, G. Taurine increases bile acid poll size and reduces bile saturation index in the hamster. J. Lipid. Res. 1987, 28, 1021-1027. [CrossRef]

67. Yokogoshi, H.; Mochizuki, H.; Nanami, K.; Hida, Y.; Miyachi, F.; Oda, H. Dietary Taurine Enhances Cholesterol Degradation and Reduces Serum and Liver Cholesterol Concentrations in Rats Fed a High-Cholesterol Diet. J. Nutr. 1999, 129, 1705-1712. [CrossRef]

68. Murakami, S.; Nara, Y.; Yamori, Y. Taurine accelerates the regression of hypercholesterolemia in stroke-prone spontaneously hypertensive rats. Life Sci. 1996, 58, 1643-1651. [CrossRef]

69. Lam, N.V.; Chen, W.; Suruga, K.; Nishimura, N.; Goda, T.; Yokogoshi, H. Enhancing effect of taurine on CYP7A1 mRN expression in Hep G2 cells. Amino Acids 2006, 30, 43-48. [CrossRef]

70. Yanagita, T.; Han, S.Y.; Hu, Y.; Nagao, K.; Kitajima, H.; Murakami, S. Taurine reduces the secretion of apolipoprotein B100 and lipids in HepG2 cells. Lipid. Health Dis. 2008, 7, 38. [CrossRef]

71. Murakami, S.; Sakurai, T.; Tomoike, H.; Sakono, M.; Nasu, T.; Fukuda, N. Prevention of hypercholesterolemia and atherosclerosis in the hyperlipidemia- and atherosclerosis-prone Japanese (LAP) quail by taurine supplementation. Amino Acids 2010, 38, 271-278. [CrossRef] [PubMed]

72. Ahn, C.S. Effect of Taurine Supplementation on Plasma Homocysteine Levels of the Middle-Aged Korean Women. Adv. Exp. Med. Biol. 2009, 643, 415-422. [CrossRef] [PubMed]

73. Zulli, A.; Lau, E.; Wijaya, B.P.P.; Jin, X.; Sutarga, K.; Schwartz, G.D.; Leamont, J.; Wookey, P.J.; Zinellu, A.; Carru, C.; et al. High dietary taurine reduces apoptosis and atherosclerosis in the left main coronary artery. Hypertension 2009, 53, 1017-1022. [CrossRef] [PubMed]

74. Gokce, G.; Ozsarlak-Sozer, G.; Oran, I.; Oktay, G.; Ozkal, S.; Kerry, Z. Taurine suppresses oxidative stress-potentiated expression of lectin-like oxidized low-density lipoprotein receptor and restensosis in balloon-injured rabbit iliac artery. Clin. Exp. Pharmacol. Physiol. 2011, 38, 811-818. [CrossRef] [PubMed]

75. Ulrich-Merzenich, G.; Zeitler, H.; Vetter, H.; Bhonde, R.R. Protective effects of taurine on endothelial cells impaired by high glucose and oxidized low density lipoproteins. Eur. J. Nutr. 2007, 46, 431-438. [CrossRef] 
76. Yoshimura, H.; Nariai, Y.; Etshima, M.; Mitani, T.; Tanigawa, Y. Taurine suppresses platelet-derived growth factor (PDGF) BB-induced PDGF-beta receptor phosphorylation by protein tyrosine phosphatase-mediated dephosphorylation in vascular smooth muscle cells. Biochim. Biophys. Acta 2005, 1745, 350-360. [CrossRef]

77. Guizoni, D.M.; Vettorazzi, J.F.; Carneiro, E.M.; Davel, A.P. Modulation of endothelium-derived nitric oxide production and activity by taurine and taurine-conjugated bile acids. Nitric Oxide 2020, 94, 48-53. [CrossRef]

78. Rosca, A.; Stancu, C.S.; Badiu, C.; Popescu, B.O.; Mirica, R.; Căruntu, C.; Gologan, S.; Voiculescu, S.E.; Zagrean, A.-M. Lipid Profile Changes Induced by Chronic Administration of Anabolic Androgenic Steroids and Taurine in Rats. Medicina 2019, 55, 540. [CrossRef]

79. Chen, W.; Guo, J.-X.; Chang, P. The effect of taurine on cholesterol metabolism. Mol. Nutr. Food Res. 2012, 56, 681-690. [CrossRef]

80. Murakami, S. Role of taurine in the pathogenesis of obesity. Mol. Nutr. Food Res. 2015, 59, 1353-1363. [CrossRef]

81. Ito, T.; Schaffer, S.W.; Azuma, J. The potential usefulness of taurine on diabetes mellitus and its complications. Amino Acids 2012, 42, 1529-1539. [CrossRef] [PubMed]

82. Das, J.; Roy, A.; Sil, P.C. Mechanism of the Protective Action of Taurine in Toxin and Drug Induced Organ Pathophysiology and Diabetic Complications: A Review. Food Funct. 2012, 3, 1251-1264. [CrossRef] [PubMed]

83. Imae, M.; Asano, T.; Murakami, S. Potential role of taurine in the prevention of diabetes and metabolic syndrome. Amino Acids 2012, 46, 81-88. [CrossRef]

84. Sirdah, M.M. Protective and therapeutic effectiveness of taurine in diabetes mellitus: A rationale for antioxidant supplementation. Diabetes Metab. Syndr. Clin. Res. Rev. 2015, 9, 55-64. [CrossRef]

85. Llah, I.U.; Piao, F.; Aadil, R.M.; Suleman, R.; Li, K.; Zhang, M.; Wu, P.; Shahbaz, M.; Ahmed, Z. Ameliorative effects of taurine against diabetes: A review. Amino Acids 2018, 50, 487-502. [CrossRef] [PubMed]

86. Baron, A.D. Vascular reactivity. Am. J. Cardiol. 1999, 84, 25J-27J. [CrossRef]

87. O'Connell, B.J.; Genest, J., Jr. High-density lipoproteins and endothelial function. Circulation 2001, 104, 1978-1983. [CrossRef]

88. Fowler, B. Homocystein-An independent risk factor for cardiovascular and thrombotic diseases. Ther. Umsch. 2005, 62, 641-646. [CrossRef]

89. Sudano, I.; Roas, S.; Noll, G. Vascular abnormalities in essential hypertension. Curr. Pharm. Des. 2011, 17, 3039-3044. [CrossRef]

90. Lei, J.; Vodovotz, Y.; Tzeng, E.; Billiar, T.R. Nitric oxide, a protective molecule in the cardiovascular system. Nitric Oxide 2013, 35, 175-185. [CrossRef]

91. Kim, Y.-W.; West, X.Z.; Byzova, T.V. Inflammation and oxidative stress in angiogenesis and vascular disease. Klin. Wochenschr. 2013, 91, 323-328. [CrossRef] [PubMed]

92. van der Stoep, M.; Korporaal, S.J.; Van Eck, M. High-density lipoprotein as a modulator of platelet and coagulation responses. Cardiovasc. Res. 2014, 103, 362-371. [CrossRef] [PubMed]

93. Baszczuk, A.; Kopczyński, Z.; Thielemann, A. Endothelial dysfunction in patients with primary hypertension and hyperhomocysteinemia. Postepy Hig. Med. Dosw. 2014, 68, 91-100. [CrossRef] [PubMed]

94. Chan, L.; Luo, X.; Ni, H.; Shi, H.; Liu, L.; Wen, Z.; Gu, X.; Qiao, J.; Li, J. High levels of LDL-C combined with low levels of HDL-C further increase platelet activation in hypercholesterolemic patients. Braz. J. Med Biol. Res. 2015, 48, 167-173. [CrossRef]

95. Aird, W.C. Endothelium and haemostasis. Hamostaseologie 2015, 35, 11-16. [CrossRef]

96. Fraer, M.; Kilic, F. Serotonin: A different player in hypertension-associated thrombosis. Hypertension 2015, 65, 942-948. [CrossRef]

97. Azuma, M.; Takahashi, K.; Fukuda, T.; Ohyabu, Y.; Yamamoto, I.; Kim, S.; Iwao, H.; Schaffer, S.W.; Azuma, J. Taurine attenuates hypertrophy induced by angiotensin II in cultured neonatal rat cardiac myocytes. Eur. J. Pharmacol. 2000, 403, 181-188. [CrossRef]

98. Schaffer, S.; Solodushko, V.; Pastukh, V.; Ricci, C.; Azuma, J. Possible Cause of Taurine-deficient Cardiomyopathy: Potentiation of Angiotensin II Action. J. Cardiovasc. Pharmacol. 2003, 41, 751-759. [CrossRef]

99. Oudit, G.Y.; Trivieri, M.G.; Khaper, N.; Husain, T.; Wilson, G.J.; Liu, P.; Sole, M.J.; Backx, P.H. Taurine Supplementation Reduces Oxidative Stress and Improves Cardiovascular Function in an Iron-Overload Murine Model. Circulation 2004, 109, $1877-1885$. [CrossRef]

100. Li, C.; Cao, L.; Zeng, Q.; Liu, X.; Zhang, Y.; Dai, T.; Hu, D.; Huang, K.; Wang, Y.; Wang, X.; et al. Taurine May Prevent Diabetic Rats from Developing Cardiomyopathy also by Downregulating Angiotensin II Type2 Receptor Expression. Cardiovasc. Drugs Ther. 2005, 19, 105-112. [CrossRef]

101. Ito, T.; Schaffer, S.; Azuma, J. The effect of taurine on chronic heart failure: Actions of taurine against catecholamine and angiotensin II. Amino Acids 2014, 46, 111-119. [CrossRef] [PubMed]

102. Ito, T.; Hanahata, Y.; Kine, K.; Murakami, S.; Schaffer, S.W. Tissue Taurine Depletion Induces Profibrotic Pattern of Gene Expression and Causes Aging-Related Cardiac Fibrosis in Heart in Mice. Biol. Pharm. Bull. 2018, 41, 1561-1566. [CrossRef] [PubMed]

103. McCarty, M.F. Practical prevention of cardiac remodeling and atrial fibrillation with full-spectrum antioxidant therapy and ancillary strategies. Med. Hypotheses 2010, 75, 141-147. [CrossRef] [PubMed]

104. Brass, L. Understanding and Evaluating Platelet Function. Hematology 2010, 2010, 387-396. [CrossRef] [PubMed]

105. Estevez, B.; Du, X. New Concepts and Mechanisms of Platelet Activation Signaling. Physiology 2017, 32, 162-177. [CrossRef]

106. Rivera, J.; Lozano, M.L.; Navarro-Núñez, L.; Vicente, V. Platelet receptors and signaling in the dynamics of thrombus formation. Haematologica 2009, 94, 700-711. [CrossRef]

107. Varga-Szabo, D.; Braun, A.; Nieswandt, B. Calcium signaling in platelets. J. Thromb. Haemost. 2009, 7, 1057-1066. [CrossRef] 
108. McCarty, M.F. Complementary vascular-protective actions of magnesium and taurine: A rationale for magnesium taurate. Med. Hypotheses 1996, 46, 89-100. [CrossRef]

109. Maupin, B. Blood Platelets in Man and Animals; Pergamon Press: Oxford, UK, 1969; pp. 1-487, ISBN 9781483282978. [CrossRef]

110. Ahtee, L.; Boullini, D.J.; Paasonen, M.K. Transport of taurine by normal human blood platelets. Br. J. Pharmac. 1974, 52, $245-251$. [CrossRef]

111. Vinton, N.E.; Laidlaw, S.A.; Ament, M.E.; Kopple, J.D. Taurine concentrations in plasma and blood cells of patients undergoing long-term parenteral nutrition. Am. J. Clin. Nutr. 1986, 44, 398-404. [CrossRef]

112. Laidlaw, S.A.; Sturman, J.A.; Kopple, J.D. Effect of dietary taurine on plasma and blood cell taurine concentrations in cats. J. Nutr. 1987, 117, 1945-1959. [CrossRef] [PubMed]

113. Hayes, K.; Pronczuk, A.; Addesa, A.; Stephan, Z. Taurine modulates platelet aggregation in cats and humans. Am. J. Clin. Nutr. 1989, 49, 1211-1216. [CrossRef] [PubMed]

114. De Luca, G.; Calpona, P.; Caponetti, A.; Romano, G.; Di Benedetto, A.; Cucinotta, D.; Di Giorgio, R. Taurine and osmoregulation: Platelet taurine content, uptake, and release in type 2 diabetic patients. Metabolism 2001, 50, 60-64. [CrossRef] [PubMed]

115. Voaden, M.J.; Hussain, A.A.; Chan, I.P. Studies on retinitis pigmentosa in man. I. Taurine and blood platelets. Br. J. Ophthalmol. 1982, 66, 771-775. [CrossRef]

116. Torres, C.L.; Walker, N.J.; Rogers, Q.R.; Tablin, F. Platelet Taurine Concentration Can Be Predicted from Whole Blood Taurine Concentrations in Dogs. J. Nutr. 2006, 136 (Suppl. 7), 2055S-2057S. [CrossRef]

117. Otani, F.; Ejiri, K.; Kanemori, H.; Kudo, T.; Sekiba, K. Platelet taurine concentration and uptake in gestosis patients with edema, proteinuria and hypertension. Acta Med. Okayama 1992, 46, 17-22. [CrossRef]

118. Spohr, C.; Brøns, C.; Winther, K.; Dyerberg, J.; Vaag, A. No effect of taurine on platelet aggregation in men with a predisposition to type 2 diabetes mellitus. Platelets 2005, 16, 301-305. [CrossRef]

119. Miglis, M.; Wilder, D.; Reid, T.; Bakaltcheva, I. Effect of taurine on platelets and the plasma coagulation system. Platelets 2002, 13, 5-10. [CrossRef]

120. Weingarten, F. Darstellung von Homologen des Taurins und von Polymethylen-dithioschwefelsauren Salzen und Prüfung ihrer Wirkung auf die Blutgerinnung [The production of homologues of taurine and of polymethylene dithiosulfonic acid salts and examination of their effect on blood coagulation]. Arzneimittelforschung 1954, 4, 344-346.

121. Krøll, J.; Krøsll, J. Influence of Bile Salts on the Lysis of131I-Labelled Plasma Clots in Human Subcutaneous Tissuein Vivo. Scand. J. Clin. Lab. Investig. 1966, 18, 691-692. [CrossRef]

122. Baele, G.; Beke, R.; Barbier, F. In vitro inhibition of platelet aggregation by bile salts. Thromb. Haemost. 1980, 44, 62-64. [CrossRef] [PubMed]

123. Takano, S.; Suzuki, T. Effect of Bile on Aggregation and Morphology of Rabbit Platelets. Tohoku J. Exp. Med. 1980, 131, 71-78. [CrossRef] [PubMed]

124. Krauss, J.S.; Jonah, M.H. Platelet Dysfunction (Thrombocytopathy) in Extrahepatic Biliary Obstruction. South Med. J. 1982, 75, 506-507. [CrossRef] [PubMed]

125. Bowen, D.J.; Clemmons, R.M.; Meyer, D.J.; Dorsey-Lee, M.R. Platelet functional changes secondary to hepatocholestasis and elevation of serum bile acids. Thromb. Res. 1988, 52, 649-654. [CrossRef]

126. Kurachi, M.; Hongoh, K.; Watanabe, A.; Aihara, H. Suppression of bronchial response to platelet activating factor following taurine administration. Adv. Exp. Med. Biol. 1987, 217, 189-198. [CrossRef] [PubMed]

127. El Tahir, K.E.; Ageel, A.M.; Abu-Jayyab, A.R. Effect of taurine on arterial, uterine and cardiac PGI2 and TXA2 synthesis in the rat. Prostaglandins 1987, 33, 17-24. [CrossRef]

128. Hofmann, J.; Lösche, W.; Till, U.; Bosia, A.; Arese, P.; Pescarmona, G.P.; Thielmann, K. Effect of decreased GSH level on human platelet functions. Artery 1980, 8, 431-436.

129. Harpster, N.K. Feline Cardiomyopathy. Vet. Clin. N. Am. 1977, 7, 355-371. [CrossRef]

130. Welles, E.G.; Boudreaux, M.K.; Tyler, J.W. Platelet, antithrombin, and fibrinolytic activities in taurine-deficient and taurine-replete cats. Am. J. Vet. Res. 1993, 54, 1235-1243.

131. Ji, Y.; Tao, L.; Xu, H.L.; Rao, M.R. Effects of taurine and enalapril on blood pressure, platelet aggregation and the regression of left ventricular hypertrophy in two-kidney-one-clip renovascular hypertensive rats. Yao Xue Xue Bao 1995, 30, 886-890.

132. Park, I.S.; Kang, Y.H.; Kang, J.S. Effects of taurine on plasma and liver lipids, erythrocyte ouabain sensitive Na efflux and platelet aggregation in Sprague Dawley rats. Nutr. Res. Pract. 2007, 1, 200-205. [CrossRef] [PubMed]

133. Rosca, A.; Badiu, C.; Uscatescu, V.; Mirica, R.; Bragam, R.; Pavel, B.; Zagrean, L. Effect of chronic administration of anabolic androgenic steroids and taurine on platelet aggregation in rats. Acta Endocrinol. 2013, 9, 33-38. [CrossRef]

134. Roşca, A.E.; Badiu, C.; Uscătescu, V.; Stoian, I.; Mirică, R.; Braga, R.I.; Pavel, B.; Zăgrean, L. Influence of chronic administration of anabolic androgenic steroids and taurine on haemostasis profile in rats: A thrombelastographic study. Blood Coagul. Fibrinolysis 2013, 24, 256-260. [CrossRef] [PubMed]

135. Murina, M.A.; Savel'eva, E.L.; Roshchupkin, D.I. Mechanism of action of biogenic chloramines and hypochlorite on initial aggregation of blood platelets. Biofizika 2006, 51, 299-305.

136. Murina, M.A.; Roshchupkin, D.I.; Kravchenko, N.N.; Petrova, A.O.; Sergienko, V.I. Antiaggregant effects of biogenic chloramines. Bull. Exp. Biol. Med. 2007, 144, 464-470. [CrossRef] 
137. Murina, M.A.; Roshchupkin, D.I.; Chudina, N.A.; Petrova, A.O.; Sergienko, V.I. Antiaggregant effect of taurine chloramines in the presence of serum albumin. Bull. Exp. Biol. Med. 2009, 147, 704-707. [CrossRef]

138. Roshchupkin, D.I.; Murina, M.A.; Sergienko, V.I. Covalent chloramine inhibitors of blood platelet functions: Computational indices for their reactivity and antiplatelet activity. Biofizika 2011, 56, 945-954. [CrossRef]

139. Murina, M.A.; Roshchupkin, D.I.; Kondrashova, K.V.; Sergienko, V.I. Inhibition of Plasma Coagulation and Platelet Aggregation with Structural Analogs of Taurine Chloramine. Bull. Exp. Biol. Med. 2014, 157, 207-210. [CrossRef]

140. Almazov, V.A.; Gurevich, V.S.; Mikhaŭlova, I.A.; Strel'tsova, E.N. Effect of taurine on Ca, Mg-ATPase activity in human platelets and on their aggregation. Bull. Exp. Biol. Med. 1985, 100, 398-400. (In Russian) [CrossRef]

141. Raghu, C.N.; Manikeri, S.R.; Sheth, U.K.; Dadkar, V.N. Probable mode of taurine action. Indian J. Exp. Biol. 1982, $20,481-483$.

142. Thomas, G.; Lucas, F.V.; Schumacher, O.P.; Skrinska, V. Behavior of intracellular glutathione during platelet thromboxane synthesis in diabetes. Prostaglandins. Leukot. Med. 1986, 22, 117-128. [CrossRef]

143. Franconi, F.; Miceli, M.; Bennardini, F.; Mattana, A.; Covarrubias, J.; Seghieri, G. Taurine potentiates the antiaggregatory action of aspirin and indomethacin. Adv. Exp. Med. Biol. 1992, 315, 181-186. [CrossRef] [PubMed]

144. McCarty, M.F. Sub-optimal taurine status may promote platelet hyperaggregability in vegetarians. Med. Hypotheses 2004, 63, 426-433. [CrossRef]

145. Franconi, F.; Bennardini, F.; Mattana, A.; Miceli, M.; Ciuti, M.; Milan, M.; Gironi, A.; Bartomomei, G.; Anichini, R.; Seghieri, G. Taurine levels in plasma and platelets in insulin-dependent and non-insulin-dependent diabetes mellitus: Correlation with platelet aggregation. Adv. Exp. Med. Biol. 1994, 359, 419-424. [CrossRef] [PubMed]

146. Franconi, F.; Bennardini, F.; Mattana, A.; Miceli, M.; Ciuti, M.; Milan, M.; Gironi, A.; Anichini, R.; Seghieri, G. Plasma and platelet taurine are reduced in subjects with insulin-dependent diabetes mellitus: Effects of taurine supplementation. Am. J. Clin. Nutr. 1995, 61, 1115-1119. [CrossRef]

147. Geggel, H.S.; Ament, M.E.; Heckenlively, J.R.; Martin, D.A.; Kopple, J.D. Nutritional requirement for taurine in patients receiving long-term parenteral nutrition. N. Engl. J. Med. 1985, 312, 142-146. [CrossRef]

148. Trachtman, H.; Del Pizzo, R.; Futterweit, S.; Levine, D.; Rao, P.S.; Valderrama, E.; Sturman, J.A. Taurine attenuates renal disease in chronic puromycin aminonucleoside nephropathy. Am. J. Physiol. Physiol. 1992, 262, F117-F123. [CrossRef]

149. Douglas, J.T.; Shah, M.; Lowe, G.D.; Belch, J.J.; Forbes, C.D.; Prentice, C.R. Plasma fibrinopeptide A and beta-thromboglobulin in pre-eclampsia and pregnancy hypertension. Thromb. Haemost. 1982, 47, 54-55. [CrossRef] [PubMed]

150. Nakabayashi, M. The role of coagulation and fibrinolysis system in pathogenesis of toxemia of pregnancy. Nihon Sanka Fujinka Gakkai Zasshi 1988, 40, 1000-1009.

151. Ornaghi, S.; Mueller, M.; Barnea, E.R.; Paidas, M.J. Thrombosis during pregnancy: Risks, prevention, and treatment for mother and fetus-harvesting the power of omic technology, biomarkers and in vitro or in vivo models to facilitate the treatment of thrombosis. Birth Defects Res. C Embryo. Today 2015, 105, 209-225. [CrossRef]

152. Valera, M.C.; Parant, O.; Vayssiere, C.; Arnal, J.F.; Payrastre, B. Physiologic and pathologic changes of platelets in pregnancy. Platelets 2010, 21, 587-595. [CrossRef] [PubMed]

153. Jakobsen, C.; Larsen, J.B.; Fuglsang, J.; Hvas, A.-M. Platelet function in preeclampsia-A systematic review and meta-analysis. Platelets 2019, 30, 549-562. [CrossRef] [PubMed]

154. Namba, K.; Ejiri, K.; Kanemori, H.; Kudo, T.; Sekiba, K. Effect of taurine concentration on platelet aggregation in gestosis patients with edema, proteinuria and hypertension. Acta. Med. Okayama 1992, 46, 241-247. [PubMed]

155. White, J.G.; Rao, G.H.; Gerrard, J.M. Effects of the lonophore A23187 on blood platelets I. Influence on aggregation and secretion. Am. J. Pathol. 1974, 77, 135-149. [PubMed]

156. Atahanov, S.E.; Elizarova, E.P. Modulation of receptor-dependent increase of calcium ions in human platelets by taurine. Arzneimittelforschung 1992, 42, 1311-1313.

157. Santhakumar, A.; Fozzard, N.; Perkins, A.; Singh, I. The Synergistic Effect of Taurine and Caffeine on Platelet Activity and Hemostatic Function. Food Public Health 2013, 3, 147-153. [CrossRef]

158. Roshchupkin, D.I.; Murina, M.A.; Adnoral, N.V.; Kravchenko, N.N.; Sergienko, V.I. Inhibition of platelet function by biogenic chloramines. Fiziol. Cheloveka 1998, 24, 113-120.

159. Roshchupkin, D.I.; Berzhitskaia, V.V.; Sokolov, A.; Murina, M.A. Changes in the initial platelet aggregation during storage of the platelet concentrate and exposure to the myeloperoxidase reaction products. Bull. Eksp. Biol. Med. 1997, 124, 523-526.

160. Murina, M.A.; Roshchupkin, D.I.; Kravchenko, N.N.; Sadovnikov, V.B.; Sergienko, V.I. The anti-aggregatory effect of chloramine derivatives of amino acids on platelets in the presence of plasma. Biofizika 1997, 42, 1279-1285.

161. Rpshchupkin, D.I.; Berzhitskaia, V.V.; Murina, M.A. Difference in inhibitory actions of products of the myeloperoxidase- catalyzed reaction on initial aggregation of activated platelets. Biofizika 1998, 43, 323-328.

162. Elizarova, E.P. Effects of taurine on calcium in platelets and their aggregation. Adv. Exp. Med. Biol. 1996, 403, 589-595. [CrossRef] [PubMed]

163. Sun, Q.; Wang, B.; Li, Y.; Sun, F.; Li, P.; Xia, W.; Zhou, X.; Li, Q.; Wang, X.; Chen, J.; et al. Taurine Supplementation Lowers Blood Pressure and Improves Vascular Function in Prehypertension: Randomized, Double-Blind, Placebo-Controlled Study. Hypertension 2016, 67, 541-549. [CrossRef] [PubMed] 
164. DiNicolantonio, J.J.; Okeefe, J.H.; McCarty, M.F. Boosting endogenous production of vasoprotective hydrogen sulfide via supplementation with taurine and N-acetylcysteine: A novel way to promote cardiovascular health. Open Heart 2017, 4, e000600. [CrossRef] [PubMed]

165. McCarty, M.F.; O'Keefe, J.H.; DiNicolantonio, J.J. A diet rich in taurine, cysteine, folate, B12 and betaine may lessen risk for Alzheimer's disease by boosting brain synthesis of hydrogen sulfide. Med. Hypotheses 2019, 132, 109356. [CrossRef] [PubMed]

166. Baseggio Conrado, A.; Capuozzo, E.; Mosca, L.; Francioso, A.; Fontana, M. Thiotaurine: From Chemical and Biological Properties to Role in H2S Signaling. Adv. Exp. Med. Biol. 2019, 1155, 755-771. [CrossRef] [PubMed]

167. Pircher, J.; Fochler, F.; Czermak, T.; Mannell, H.; Kraemer, B.F.; Wörnle, M.; Sparatore, A.; Del Soldato, P.; Pohl, U.; Krötz, F. Hydrogen Sulfide-Releasing Aspirin Derivative ACS14 Exerts Strong Antithrombotic Effects In Vitro and In Vivo. Arter. Thromb. Vasc. Biol. 2012, 32, 2884-2891. [CrossRef]

168. Gao, L.; Cheng, C.; Sparatore, A.; Zhang, H.; Wang, C. Hydrogen sulfide inhibits human platelet aggregation in vitro in part by interfering gap junction channels: Effects of ACS14, a hydrogen sulfide-releasing aspirin. Heart Lung Circ. 2015, $24,77-85$. [CrossRef]

169. Grambow, E.; Mueller-Graf, F.; Delyagina, E.; Frank, M.; Kuhla, A.; Vollmar, B. Effect of the hydrogen sulfide donor GYY4137 on platelet activation and microvascular thrombus formation in mice. Platelets 2014, 25, 166-174. [CrossRef]

170. Zhong, L.; Lv, L.; Yang, J.; Liao, X.; Yu, J.; Wang, R.; Zhou, P. Inhibitory Effect of Hydrogen Sulfide on Platelet Aggregation and the Underlying Mechanisms. J. Cardiovasc. Pharmacol. 2014, 64, 481-487. [CrossRef]

171. Zhao, Z.; Liu, X.; Shi, S.; Li, H.; Gao, F.; Zhong, X.; Wang, Y. Exogenous hydrogen sulfide protects from endothelial cell damage, platelet activation, and neutrophils extracellular traps formation in hyperhomocysteinemia rats. Exp. Cell Res. 2018, 370, 434-443. [CrossRef]

172. Zhang, H.; Bai, Z.; Zhu, L.; Liang, Y.; Fan, X.; Li, J.; Wen, H.; Shi, T.; Zhao, Q.; Wang, Z. Hydrogen sulfide donors: Therapeutic potential in anti-atherosclerosis. Eur. J. Med. Chem. 2020, 205, 112665. [CrossRef] [PubMed]

173. Fennessy, F.; Moneley, D.; Wang, J.; Kelly, C.; Bouchier-Hayes, D. Taurine and Vitamin C Modify Monocyte and Endothelial Dysfunction in Young Smokers. Circulation 2003, 107, 410-415. [CrossRef] [PubMed]

174. Tan, B.; Jiang, D.-J.; Huang, H.; Jia, S.-J.; Jiang, J.-L.; Hu, C.-P.; Li, Y.-J. Taurine protects against low-density lipoprotein-induced endothelial dysfunction by the DDAH/ADMA pathway. Vasc. Pharmacol. 2007, 46, 338-345. [CrossRef] [PubMed]

175. Hu, J.; Xu, X.; Yang, J.; Wu, G.; Sun, C.; Lv, Q. Antihypertensive Effect of Taurine in Rat. Adv. Exp. Med. Biol. 2009, 643, 75-84. [CrossRef] [PubMed]

176. Maia, A.R.; Batista, T.M.; Victorio, J.A.; Clerici, S.P.; Delbin, M.A.; Carneiro, E.M.; Davel, A.P. Taurine supplementation reduces blood pressure and prevents endothelial dysfunction and oxidative stress in post-weaning protein-restricted rats. PLoS ONE. 2014, 9, e105851. [CrossRef]

177. Yamamoto, J.; Akabane, S.; Yoshimi, H.; Nakai, M.; Ikeda, M. Effects of taurine on stress-evoked hemodynamic and plasma catecholamine changes in spontaneously hypertensive rats. Hypertension 1985, 7, 913-922. [CrossRef]

178. Tanabe, Y.; Urata, H.; Kiyonaga, A.; Ikeda, M.; Tanaka, H.; Shindo, M.; Arakawa, K. Changes in Serum Concentrations of Taurine and Other Amino Acids in Clinical Antihypertensive Exercise Therapy. Clin. Exp. Hypertens. Part A Theory Pract. 1989, 11, 149-165. [CrossRef]

179. Fujita, T.; Sato, Y.; Ando, K. Changes in cardiac and hypothalamic noradrenergic activity with taurine in DOCA-salt rats. Am. J. Physiol. Circ. Physiol. 1986, 251, H926-H933. [CrossRef] [PubMed]

180. Chanh, P.H.; Chahine, R.; Dossou-Gbete, V.; Navarro-Delmasure, C. Taurine and icosanoids in the heart. Prostaglandins Leukot. Med. 1987, 28, 243-254. [CrossRef]

181. Wettstein, M. Cytoprotection by the osmolytes betaine and taurine in ischemia- reoxygenation injury in the perfused rat liver. Hepatology 1997, 26, 1560-1566. [CrossRef]

182. Liu, Y.; Niu, L.; Zhang, W.; Cui, L.; Zhang, X.; Liang, Y.; Zhang, M. Effects of taurine on contractions of the porcine coronary artery. Pharmacol. Rep. 2009, 61, 681-689. [CrossRef]

183. Hu, D.H. Effects of taurine enhancement of synthesis of TxA2 and PGI2 in cultured intra-pulmonary arteriolar smooth muscle cells under acute hypoxia. Sheng Li Xue Bao 1998, 50, 465-468. (In Chinese) [PubMed] 